\title{
Effect of Nanoparticles on Modified Screen Printed Inhibition Superoxide Dismutase Electrodes for Aluminum
}

\author{
Miriam Barquero-Quirós ${ }^{1, *}$ and María Julia Arcos-Martínez ${ }^{2}$ \\ 1 Department of Chemistry, University of Costa Rica, CELEQ, San Pedro de Montes de Oca, \\ San José 11501-2060, Costa Rica \\ 2 Department of Chemistry, Faculty of Sciences, University of Burgos, Plaza Misael Bañuelos s/n, \\ Burgos 09001, Spain; jarcos@ubu.es \\ * Correspondence: miriam.barquero@ucr.ac.cr; Tel.: +506-2511-2442; Fax: +506-2511-2446 \\ Academic Editor: Roberto Pilloton \\ Received: 26 July 2016; Accepted: 20 September 2016; Published: 26 September 2016
}

\begin{abstract}
A novel amperometric biosensor for the determination of Al(III) based on the inhibition of the enzyme superoxide dismutase has been developed. The oxidation signal of epinephrine substrate was affected by the presence of $\mathrm{Al}(\mathrm{III})$ ions leading to a decrease in its amperometric current. The immobilization of the enzyme was performed with glutaraldehyde on screen-printed carbon electrodes modifiedwith tetrathiofulvalene (TTF) and different types ofnanoparticles. Nanoparticles of gold, platinum, rhodium and palladium were deposited on screen printed carbon electrodes by means of two electrochemical procedures. Nanoparticles were characterized trough scanning electronic microscopy, X-rays fluorescence, and atomic force microscopy. Palladium nanoparticles showed lower atomic force microscopy parameters and higher slope of aluminum calibration curves and were selected to perform sensor validation. The developed biosensor has a detection limit of $2.0 \pm 0.2 \mu \mathrm{M}$ for $\mathrm{Al}(\mathrm{III})$, with a reproducibility of $7.9 \%(\mathrm{n}=5)$. Recovery of standard reference material spiked to buffer solution was $103.8 \%$ with a relative standard deviation of $4.8 \%(n=5)$. Recovery of tap water spiked with the standard reference material was 100.5 with a relative standard deviation of $3.4 \%(n=3)$. The study of interfering ions has also been carried out.
\end{abstract}

Keywords: superoxide dismutase biosensor; aluminum; tetrathiofulvalene; screen-printed electrodes; nanoparticles

\section{Introduction}

Aluminum toxicity has been shown in vivo and in vitro, but complexity of its interactions with human organism makes it very difficult to assign the responsibility in Alzheimer's disease. It can be considered as the combined effect of oxidant action, participation on amyloid cascade, neuronal degeneration [1] and accumulation in neurofibrillary tangles. Aluminum presence favors $\mathrm{T}$ protein link trough phosphate bridge [2] and alters homeostatic ion equilibrium [3], and it has shown a strong effect on reactive oxygen species (ROS) production on living organisms, due to iron accumulation in oxidative stress [4]. Markedly, ROS impaired enzymes such as superoxide dismutase (SOD) and catalase react with radical species such as $\mathrm{O}_{2} \bullet^{-}, \mathrm{OH} \bullet^{-}$, and $\mathrm{ONNO} \bullet^{-}$. Although $\mathrm{O}_{2} \bullet^{-}$radical is not so reactive itself, in the presence of $\mathrm{Fe}^{2+}$, Fenton reaction can turn it into hydroxyl radical, which is the most potent radical. These findings show that $\mathrm{O}_{2} \bullet-$ is involved in cellular damage. Biosensors have employed superoxide dismutase (SOD), an enzyme that scavenges superoxide to measure superoxide anion accordingly with the reactions [5]:

$$
\mathrm{Cu}^{2+}-\mathrm{SOD}+\mathrm{O}_{2} \bullet^{-} \rightarrow \mathrm{Cu}^{1+}-\mathrm{SOD}+\mathrm{O}_{2}
$$




$$
\mathrm{Cu}^{1+}-\mathrm{SOD}+\mathrm{O}_{2} \bullet^{-}+2 \mathrm{H}^{+} \rightarrow \mathrm{Cu}^{2+}-\mathrm{SOD}+\mathrm{H}_{2} \mathrm{O}_{2}
$$

$\mathrm{O}_{2} \bullet-$ affects cytochrome $\mathrm{c}$ (Cyt c) by oxidizing $\mathrm{Fe}^{2+}$ to $\mathrm{Fe}^{3+}$ and reducing itself to $\mathrm{H}_{2} \mathrm{O}_{2}$. $\mathrm{O}_{2} \bullet^{-}$radical levels were found to be elevated in homogenized cancerous brain tissue compared to normal human brain tissue [6]. $\mathrm{O}_{2} \bullet^{-}$is formed in living biological systems by the donation of an electron to molecular oxygen, through oxidation of semiquinone-type radicals formed in the mitochondrial electron transport chain. In its presence, free radical scavengers, enzymes such as superoxide dismutase and glutathione peroxidase (GSH-Px), decrease their antioxidant status, and lipid peroxide levels are increased.

Aluminum administration to laboratory animals induces SOD dysfunction and damage on target organs [7-10]. It has been found that zinc [11], selenium [12] and therapies used against Alzheimer's disease [13-16] have a protective role against aluminum induced toxicity, improving SOD function. Aluminum presence in humans is associated with oxidative stress [17,18].

Biosensors constructed with screen printed electrodes (SPCE) offer low detection limits, easier assembly of metallic nanoparticles (NPs), good reproducibility, low contamination and excellent biocompatibility with enzymes and antibodies [18]. The metal NPs' small size, high mechanical strength and high chemical and thermal stability allow them, when acting as enzyme-carrier materials, to improve the efficiency of immobilized enzymes, facilitating reaction kinetics, and supplying a larger surface area, leading to higher enzyme loading per unit mass of particles. This fact allows achieving enhanced device sensitivity and reduced mass transfer resistance [19]. Besides, NPs increased electric conductivity and electron transfer between redox enzyme center and electrode [20,21].

Different types of NPs such as metal, metal oxides, semiconductors, polymers and composite-metal NPs have been used to assembly miniaturized electrochemical sensors and biosensors. Gold NPs (AuNPs), due to their unique properties, relatively low cost and ease of preparation, are the most used in many biochemical applications [22,23]. AuNPs can be synthesized by different chemical methods and applied to electrochemical detection of As(III) [24]. AuNPs use in amperometric biosensors and electrochemical techniques enhances detection sensitivity [25-27].

Due to their inertness, platinum NPs (PtNPs) are the principal metal NPs alternative for anodic current measurement and have been applied to formaldehyde [28], neurotransmitters [29], glucose [30], uric acid [31], and As(III) determination [32].

Glassy carbon electrodes modified with palladium nanoparticles (PdNPs) have been applied to catecholamines determination [33]. PtNPs and PdNPs/methylthiophene (PMT) sensors have been applied to dopamine (DA) and AA determination [34].

Rhodium NPs' (RhNPs) main application has been as precursors for the preparation of catalytics [35,36] and for catalysis and sensing of cytochrome c [37] and $\mathrm{H}_{2} \mathrm{O}_{2}$ [38], as well as for biosensing of $\alpha$-ketoglutarate [39].

Due to sensitivity and specificity joint benefits produced by modified SPCEs with metallic NPs and enzymes, this research work was conducted with the goal to compare the effect of NPs of $\mathrm{Au}, \mathrm{Pt}$, $\mathrm{Pd}$ and $\mathrm{Rh}$ deposited by distinct electrochemical procedures on sensitivity of amperometric inhibition SOD by aluminum, with TTF as mediator using epinephrine (EPI) as substrate.

Most developed biosensors that immobilize SOD enzyme in a carrageenan gel are based on $\mathrm{H}_{2} \mathrm{O}_{2}$ amperometric detection [40] and were successfully applied as a tool for antioxidant capacity assessment to evaluate red and white wines [41], fresh herbs and fruits, olives, tea [42-44], algae [45], phytoterapeutic preparations [46], drugs containing salicylic and as corbic acid, and $\beta$-carotene [40,47]. This developed biosensor enables measurement of antioxidant capacity of healthy and diseased tissues in vitro [40], and was also applied to determination of total antioxidant capacity of berries [48].

The others SOD based biosensors that employ modified solid electrodes are shown in Table 1. 
Table 1. SOD based biosensors applied to samples of biological interest.

\begin{tabular}{|c|c|c|c|c|c|c|c|}
\hline Technique & Electrode & Potential & Modification & Range & LOD & Sample/Analite & Reference \\
\hline $\mathrm{CV}^{1}$ & SPCE & $-0.8-+0.8 \mathrm{~V}$ & Pyrrole/SAMs & $0.5 \times 10^{-9}-5 \mathrm{M}$ & $0.5 \times 10^{-9} \mathrm{M}$ & $\begin{array}{c}\text { cultured human } \\
\text { keratinocytes } \mathrm{NO}_{2}^{-}\end{array}$ & [49] \\
\hline Amperometry & CFME $^{2}$ & $+0.25 \mathrm{~V}$ & cysteine/AuNPs & $(13-104) \times 10^{-9} \mathrm{M}$ & - & $\mathrm{O}_{2} \bullet^{-}$ & [50] \\
\hline Amperometry & SPCE & $-0.1 \mathrm{~V}$ & porous $\mathrm{Pt}-\mathrm{Pd} /$ nafion & $(16-1536) \times 10^{-6} \mathrm{M}$ & $0.13 \times 10^{-6} \mathrm{M}$ & $\begin{array}{c}\text { Cell culture } \\
\text { medium } / \mathrm{O}_{2} \bullet^{-}\end{array}$ & [51] \\
\hline $\mathrm{CV}^{1}$ Chronoamperometry & Gold electrode & $-0.2-+0.5 \mathrm{~V}$ & $\begin{array}{c}\mathrm{Au} / \mathrm{Cys} / \mathrm{SOD}^{9}, \mathrm{Au} / \mathrm{GNP} / \mathrm{Cys} / \mathrm{SOD}^{10} \text { and } \\
\mathrm{Au} / \mathrm{GNP} / \mathrm{Cys} / \mathrm{SOD} / \mathrm{Chit}^{11}\end{array}$ & $0.5-4$ Gy & $0.03 \times 10^{-6} \mathrm{M}$ & thallium 201 /water & [52] \\
\hline Amperometry & GC CFME $^{2}$ & $0.2 \mathrm{~V}$ & NTA $/ \mathrm{HT}^{7}$ & $10^{-7}-10^{-4} \mathrm{M}$ & $21 \times 10^{-9} \mathrm{M}$ & brain tissue $/ \mathrm{O}_{2} \bullet^{-}$ & [53] \\
\hline \multirow{2}{*}{$\mathrm{CV}^{1}$} & $\begin{array}{c}\text { Carbon paste } \\
\text { electrode Electrochem }\end{array}$ & \multirow{2}{*}{$0-0.3 \mathrm{~V}$} & $\begin{array}{l}\text { cytochrome c in solution and } \\
\text { Fe(III)-protoporphyrin immobilized }\end{array}$ & $(1-6) \times 10^{-3} \mathrm{M}$ & $0.3 \times 10^{-3} \mathrm{M}$ & \multirow[t]{2}{*}{ Xantine } & \multirow[t]{2}{*}{ [54] } \\
\hline & System Carbon paste electrode & & Protoporphyrin and cytochrome both immobilized & $(1-8) \times 10^{-3} \mathrm{M}$ & $0.2 \times 10^{-3} \mathrm{M}$ & & \\
\hline Cronoamperometry & Composite electrode & $-0.3 \mathrm{~V}$ & PtPd-PDARGO $^{6}$ & $(0.016-0.24) \times 10^{-3} \mathrm{M}$ & $2 \times 10^{-6} \mathrm{M}$ & $\operatorname{DMEM}^{5} / \mathrm{O}_{2} \bullet-$ & [55] \\
\hline \multirow{2}{*}{ Amperometry } & \multirow{2}{*}{$\mathrm{GC}^{8}$} & \multirow{2}{*}{$-0.3 \mathrm{~V}$} & MWCNT $^{4}$ & \multirow{2}{*}{$(0.01-0.3) \times 10^{-3} \mathrm{M}$} & \multirow{2}{*}{$1 \times 10^{-6} \mathrm{M}$} & Wines, berry & \multirow{2}{*}{ [56] } \\
\hline & & & PEDOT $^{3}$ & & & juice $/ \mathrm{O}_{2} \bullet^{-}$ & \\
\hline \multirow{3}{*}{ Amperometry } & \multirow{3}{*}{$\mathrm{SPC}_{\mathrm{TTF}} \mathrm{E}^{12}$} & \multirow{3}{*}{$0.2 \mathrm{~V}$} & \multirow{3}{*}{$\mathrm{SOD} / \mathrm{PdNP}{ }^{13}$} & \multirow{3}{*}{$(1.0-60) \times 10^{-5} \mathrm{M}$} & \multirow{3}{*}{$2 \times 10^{-6} \mathrm{M}$} & $\mathrm{Al}(\mathrm{III})$ & \multirow{3}{*}{ This article } \\
\hline & & & & & & water & \\
\hline & & & & & & samples & \\
\hline
\end{tabular}

${ }^{1}$ Cyclic voltammetry; ${ }^{2}$ carbon fiber microelectrode; ${ }^{3}$ poly(3,4-ethylenedioxythiophene); ${ }^{4}$ multiwalled carbon nanotubes, ${ }^{5}$ Dulbecco's modified Eagle's medium; ${ }^{6}$ PtPd poly dopamine reduced graphene oxide; ${ }^{7}$ Nitrilotriacetic acid/histidine-tag; ${ }^{8}$ glassy carbon; ${ }^{9}$ gold, cysteine, super oxido dismutase; ${ }^{10}$ gold, gold nanoparticles cysteine, super oxido dismutase; ${ }^{11}$ gold, gold nanoparticles cysteine, super oxido dismutase, chitosane; ${ }^{12}$ screen printed carbon TTF5\% electrode; ${ }^{13}$ super oxide dismutase, palladium nanoparticles 
Taking into account that TTF allows the rapid electron transfer between SOD and electrode surface can be carried out at lower potential [57], and that pro-oxidant activity of aluminum inhibits SOD activity [58], this study indicates that Al(III) SOD inhibition can be performed at lower potential compared to other aluminum enzymatic determinations. It was shown for the first time using SPC $\mathrm{TTF}_{\mathrm{ES}}$ that $\mathrm{Al}(\mathrm{III})$ inhibits SOD enzyme linked with Alzheimer's disease at low concentrations.

\section{Materials and Methods}

\subsection{Reagents}

All solutions were prepared with purified water supplied by TKA Gen Pure, inverse osmosis, with a UV lamp irradiation system.

SOD enzyme (30 KU), EPI, bovine serum albumine (BSA), glutaraldehyde (GA) and hydrogen tetrachloroaurate (III) trihydrate $\left(\mathrm{HAuCl}_{4}\right)$ were obtained from Sigma-Aldrich (Sigma-Aldrich), Steinheim, Germany).

Solutions of platinum, rhodium and palladium $0.1 \mathrm{mM}$ were prepared from ICP solutions of $1000 \mathrm{mg} / \mathrm{L}$ (Merck, Darmstad, Germany).

Titrisol solutions from (Merck, Darmstad, Germany)were used to prepare stock standard solutions of $\mathrm{Al}(\mathrm{III}), \mathrm{Cu}(\mathrm{II}), \mathrm{Fe}(\mathrm{III}), \mathrm{Sn}(\mathrm{II}), \mathrm{Zn}(\mathrm{II}), \mathrm{Co}(\mathrm{II}), \mathrm{Ni}(\mathrm{II})$, Se(IV) Cr(III), Cd(II), Pb(II), W(VI) and V(V). Mo(VI) and $\mathrm{Ca}$ (II) solutions were obtained from Inorganic Ventures (Lakewood, NJ, USA). As(V) and Hg(II) solutions were prepared from Atomic Spectroscopy Standards solutions (Perkin Elmer Co, Whaltham, MA, USA).

Al(III) solutions used for spike were prepared from High Purity Standards (Charleston, SC, USA) confirmed against standard reference material SRM 3101.

Britton Robinson (BR) supporting electrolyte solutions were prepared as usual with boric, phosphoric and acetic acids (Merck, Darmstadt, Germany), and the required pH was obtained by adjusting with $\mathrm{NaOH}$ solution (Suprapur, Merck, Darmstadt, Germany).

Several inks were used in the fabrication of SPEs, namely Electrodag PF-407 A (carbon ink), Electrodag 6037 SS (silver/silver chloride ink) and Electrodag 452 SS (dielectric ink) supplied by Acheson Colloiden (Acheson Colloiden, Scheemda, The Netherlands).

The working electrode ink was prepared by thoroughly mixing carbon ink with tetrathiofulvalene $\left(C_{\mathrm{TTF}}\right)$ 5\%. TTF was obtained from Acros Organics (Acros Organics, Geel, Belgium).

\subsection{Equipment}

An electrochemical system Autolab PGSTAT Echo Chemie128 N with GPS software was used to record electrochemical measurements (Echo Chemie, Utrech, The Netherlands).

All pH values were adjusted with a pHmeter (Mettler Toledo, Schwerzenbach, Switzerland).

A S-3700 Hitachi was used to perform scanning electronic microscopy (SEM) of SPCEs. An IXRF Systems model 550i was used to obtain spectra of elements on the SPCE. Atomic force microscopy (AFM) parameters and images were obtained with a NanoScopeQuadrex Digital Instruments Veeco Metrology Group.

\section{$\mathrm{SPC}_{\mathrm{TTF}}$ Es Construction}

SPC $_{\text {TTFEs }}$ were homemade built using a DEK 248 printing machine (DEK, Weymouth, UK) using polyester screens with appropriate stencil designs mounted at $45^{\circ}$ to the printer stroke. These transducers consisted of three screen-printed electrodes deposited onto polyethylene terephthalate films (HiFi Industrial Film, Dardilly, France). The different inks were screen-printed and cured according to the manufacturer's specifications. The working electrode ink was prepared by thoroughly mixing carbon ink with TTF $(5 \% v / w)$ and immediately screen-printed. One electrode is shownin (Figure 1). 


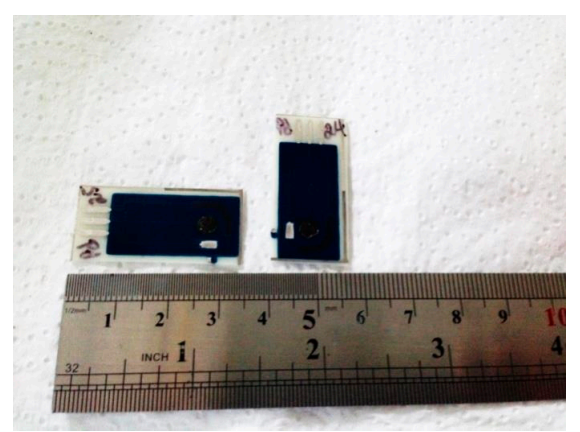

Figure 1. Screen printed electrodic system used.

\subsection{Nanoparticles Electrodeposition Methods}

$\mathrm{SPC}_{\mathrm{TTF}}$ Es modification with nanoparticles (NPs/SPC $\mathrm{TTF}_{\mathrm{T}} \mathrm{Es}$ ) was carried out by both controlled potentialand cyclic voltammetry scan methods.

(A) Metal plating was carried at two different potentials namely +0.3 and $+0.18 \mathrm{~V}$, in a quartz cell containing $\mathrm{Au}(\mathrm{III}), \mathrm{Pt}(\mathrm{IV}), \mathrm{Rh}(\mathrm{IV})$ or $\mathrm{Pd}(\mathrm{IV})$ solutions (0.1 mM) in $\mathrm{H}_{2} \mathrm{SO}_{4}$ (0.5 M) [24]. Following electrodeposition process, the NPs/SPC $\mathrm{TTF}_{\mathrm{TF}}$ was removed from platting solution, rinsed with purified water and wiped carefully.

(B) Cyclic voltammetry deposition was performed doing a set of seven successive voltammetric scans between +1.0 and -0.2 Vin a quartz cell containing $\mathrm{Au}(\mathrm{III}), \mathrm{Pt}(\mathrm{IV}), \mathrm{Rh}(\mathrm{IV})$ or $\mathrm{Pd}(\mathrm{IV})(0.1 \mathrm{mM})$ in $\mathrm{H}_{2} \mathrm{SO}_{4}(0.5 \mathrm{M})$ [59]. Electrodes were prepared by setting two cyclic voltammetric conditions namely $\mathrm{CV} 1$ and $\mathrm{CV} 2$.

CV1: delay time $60 \mathrm{~s}$, step potential $0.0150 \mathrm{~V}$, scan rate $0.050 \mathrm{~V} / \mathrm{s}$.

CV2: delay time $120 \mathrm{~s}$, step potential $0.025 \mathrm{~V}$, scan rate $0.100 \mathrm{~V} / \mathrm{s}$.

After nanoparticles deposition, the electrode was rinsed with purified water and wiped carefully.

\subsection{SOD Enzyme Immobilization onto $A u N P s / / S P C_{T T F}$ Es}

Enzyme was immobilized by crosslinking polymerization with glutaraldehyde [60] on the surfaces

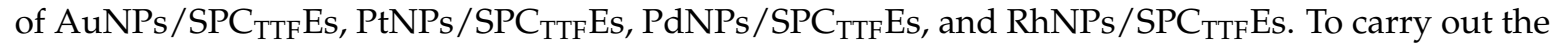
immobilization procedure, superoxide dismutase enzyme solution was prepared by dissolving enzyme in Britton Robinson buffer at pH 7.0. To avoid loss of enzymatic activity, BSA was used in a mixture made of $20 \mu \mathrm{L}$ of SOD $(5.9 \mathrm{mg} / \mathrm{mL}), 10 \mu \mathrm{L}$ of BSA $(1.69 \% w / v)$ and $10 \mu \mathrm{L}$ of GA $(2.5 \% v / v)$ [61]. This mixture was dropped onto the surface electrode and stored at $4{ }^{\circ} \mathrm{C}$ before used and between measurements. The modified electrode was washed with purified water, before and after use.

\section{Results}

\subsection{Optimization of Experimental Parameters}

EPI originates an amperometric signal at NPs/SPC $\mathrm{TTF}_{\mathrm{TF}} \mathrm{E}$ with SOD enzyme immobilized (SOD/PdNPs $/$ SPC $\left._{\mathrm{TTF}} \mathrm{E}\right)$, after which a steady-state current is reached. The presence of $\mathrm{Al}(\mathrm{III})$ ions produces SOD enzyme inhibition which causes a decrease in the EPI amperometric signal. $\mathrm{Al}(\mathrm{III})$ concentration influence inhibition process and can be quantitatively evaluated determining the difference between the steady state current in absence of $\mathrm{Al}(\mathrm{III}),\left(\mathrm{I}_{0}\right)$, and the steady state current in the presence of $\mathrm{Al}(\mathrm{III})$, (I) namely $\Delta\left(\mathrm{I}_{0}-\mathrm{I}\right)$.Accordingly, with the following working principle proposed in Scheme 1, a SOD based biosensor, with TTF incorporated in electrode ink, has been developed. 


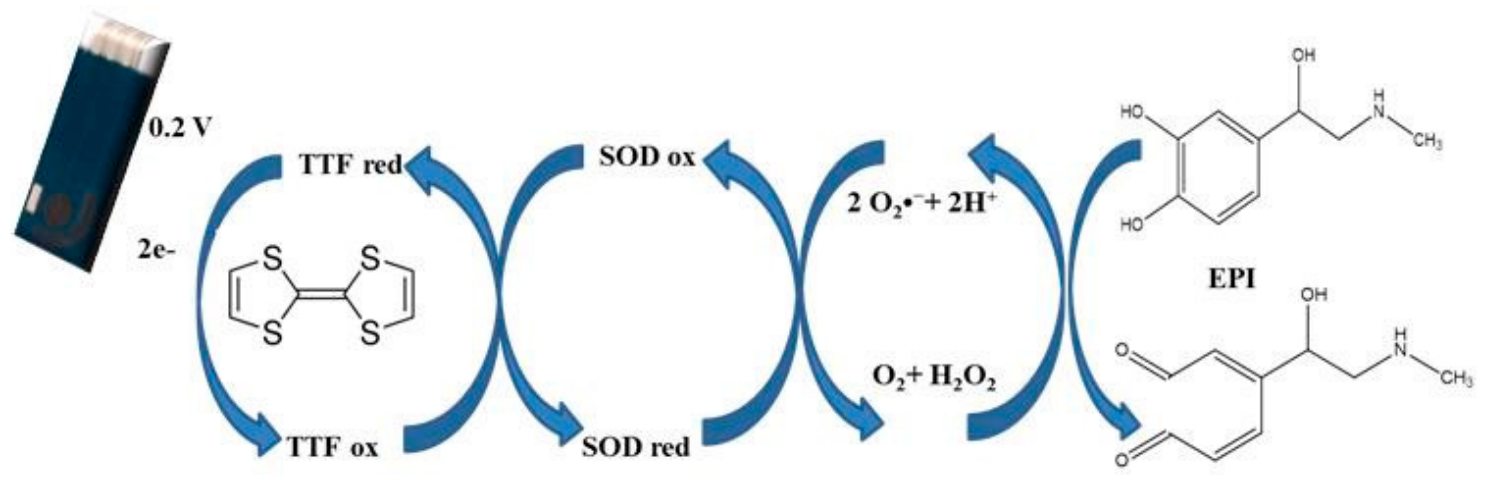

Scheme 1. Oxidation of EPI on SOD/SPC $\mathrm{TTF}_{\mathrm{T}} \mathrm{E}$.

The parameter $\Delta\left(\mathrm{I}_{0}-\mathrm{I}\right)$ depends on EPI concentration, applied potential (Eap) and $\mathrm{pH}$ solution. Therefore, an optimization of these variables was performed in order to ensure the quality of the results.

Because the dependence between $\Delta\left(\mathrm{I}_{0}-\mathrm{I}\right)$ and $\mathrm{Al}(\mathrm{III})$ concentration is linear, substrate response was obtained from $\mathrm{pH} 5.0$ to $\mathrm{pH} 8.0$, and a $\mathrm{pH}$ of 5.0 was selected regarding substrate stability to autoxidation. In the same way, substrate response was obtained from $+0.20 \mathrm{~V}$ to $+0.60 \mathrm{~V}$, and a potential of $0.2 \mathrm{~V}$ was selected driving substrate oxidation to epinephrinequinone [57]. Then, several aluminum inhibition calibration curves were performed at different potential and $\mathrm{pH}$ values and their slopes were compared, in order to obtain $\mathrm{Al}(\mathrm{III})$ inhibition effect with $\mathrm{pH}$ and Eap. Slope calibration curve with $\mathrm{pH}$ was calculated from $\mathrm{pH} 5.0$ to $\mathrm{pH}$ 8.0. In the same way, slope calibration curve with potential was calculate from $+0.20 \mathrm{~V}$ to $+0.60 \mathrm{~V}$. Higher slope values were obtained at $\mathrm{pH} 5.0$ and Eap of $+0.2 \mathrm{~V}$, so these conditions were chosen to perform Al(III) inhibition calibration curves. Slopes of calibration curves with potential and $\mathrm{pH}$ are shown in Figure 2.

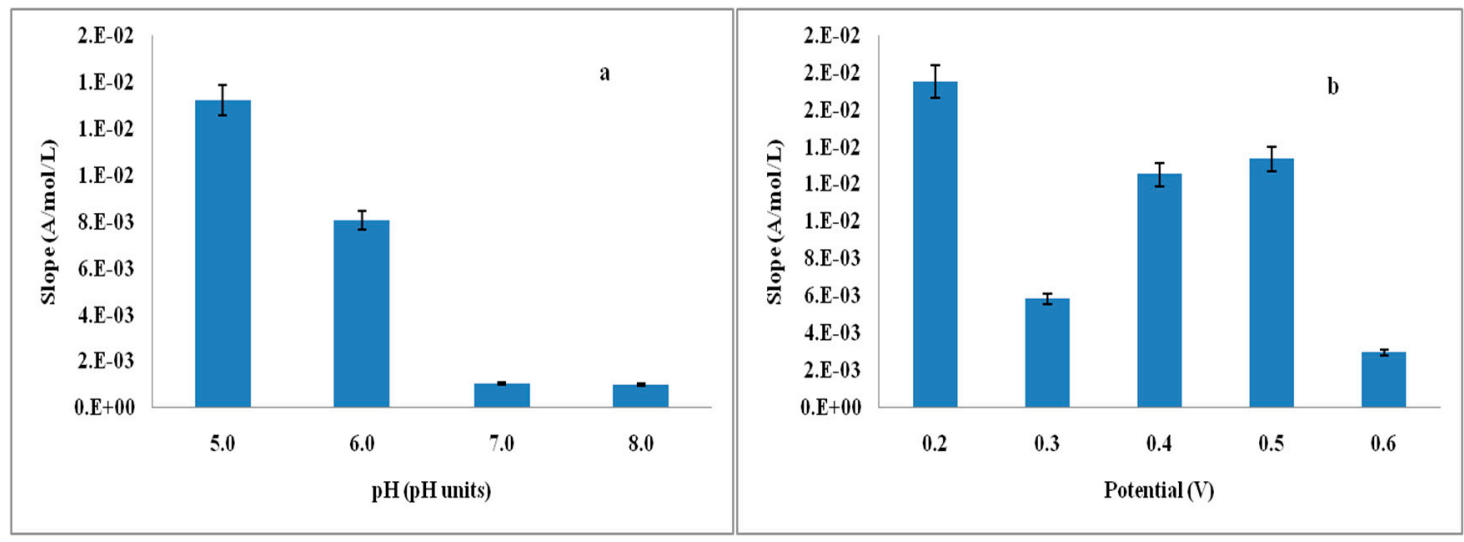

Figure 2. (a) Slope values of $\mathrm{Al}(\mathrm{III})$ calibration curves with $\mathrm{pH}$; and (b) Slope value of $\mathrm{Al}(\mathrm{III})$ calibration curves with applied potential. $[\mathrm{EPI}]=1.6 \times 10^{-4} \mathrm{M}$; Britton Robinson buffer $\mathrm{pH}$ 5.0, Eap $=+0.2 \mathrm{~V}$ vs. $\mathrm{Ag} / \mathrm{AgCl}$.

Findings indicated that substrate stability improved at low values of $\mathrm{pH}$ and potential; furthermore, if applied potentials were higher than $+0.6 \mathrm{~V}$, the electrodes showed erratic behavior. Since substrate response increases with concentration, a value of $1.6 \times 10^{-4} \mathrm{M}$ for EPI was chosen, as this concentration gives a proper sensibility, and a very stable signal with very low noise. Upper concentrations produced higher noise on amperometric recording of calibration curves. Under the selected conditions, the electrodes showed good performance. Calibration

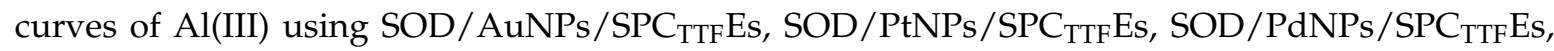
and $\mathrm{SOD} / \mathrm{RhNPs} / \mathrm{SPC}_{\mathrm{TTF}}$ Es were obtained under the optimized conditions. 
Preliminary experiments showed that modification of electrode surface with NPs increased the sensitivity of the biosensor; therefore, a thorough study of conditions of NPs deposition was carried out. AuNPs, PtNPs, PdNPs and RhNPs were deposited on electrodes surfaces according to methods described in the Experimental Section.

\subsection{XRF and SEM for NPS/SPC $T$ TTF Study METHOD A}

Two different controlled potentials, $+0.18 \mathrm{~V}$ and $+0.3 \mathrm{~V}$, were applied for $15 \mathrm{~s}$ to SPCEs in order to deposit NPs of every metal. X-ray fluorescence emission (XRF) spectra were obtained from surfaces of $\mathrm{SPC}_{\mathrm{TTF}}$ Es modified with the different type of NPs. Table 2 shows XRF percentage of elements deposited using indicated potentials.

The plating of metals at $+0.18 \mathrm{~V}$ for $15 \mathrm{~s}$ produced a higher percentage of $\mathrm{Au}, \mathrm{Pd}$ and $\mathrm{Rh}$. $\mathrm{Pt}$ deposited percentage was higher at $+0.30 \mathrm{~V}$. Since the Eap of $+0.18 \mathrm{~V}$ applied for $15 \mathrm{~s}$ produced a higher percentage for $\mathrm{Pd}, \mathrm{Rh}$ and $\mathrm{Au}$, and the application of a deposition potential of $+0.3 \mathrm{~V}$ did not deposit $\mathrm{Pd}$ or $\mathrm{Au}$, conditions of Eap of $+0.18 \mathrm{~V}$ and $15 \mathrm{~s}$ of method A were selected to deposit NPs of metals.

Table 2. XRF percentage of element deposited on $\mathrm{SPC}_{\mathrm{TTF}}$ Es by method A and B.

\begin{tabular}{ccccc}
\hline & \multicolumn{2}{c}{ Method A } & \multicolumn{2}{c}{ Method B } \\
\hline \multirow{2}{*}{ Element } & XRF\% & XRF\% & XRF\% & XRF\% \\
\cline { 2 - 5 } & $(+0.18 \mathrm{~V}, 15 \mathrm{~s})$ & $(+0.30 \mathrm{~V}, 15 \mathrm{~s})$ & $\mathrm{CV} 1$ & $\mathrm{CV} 2$ \\
\hline $\mathrm{Pd}$ & 0.136 & 0.00 & 0.557 & 0.632 \\
$\mathrm{Pt}$ & 0.223 & 1.48 & 2.74 & 2.71 \\
$\mathrm{Rh}$ & 0.693 & 0.380 & 4.49 & 2.95 \\
$\mathrm{Au}$ & 1.42 & - & 1.87 & 2.23 \\
\hline
\end{tabular}

The inhibition calibration curves for $\mathrm{Al}(\mathrm{III})$ are shown in Figure 3, where the lowest slope value corresponds to $\mathrm{SPC}_{\mathrm{TTF}} \mathrm{E}$ without NPs deposited and the highest corresponds to SOD/AuNPs $\mathrm{SPC}_{\mathrm{TTF}} \mathrm{E}$. The other metal NPs modified $\mathrm{SPC}_{\mathrm{TTF}} \mathrm{E}$ tested showed lower linear adjustment than SOD/AuNPs SPC TTFE.

SEM images of AuNPs obtained by method A deposited on $\mathrm{SPC}_{\mathrm{TTF}} \mathrm{E}$ are presented in Figure 4.

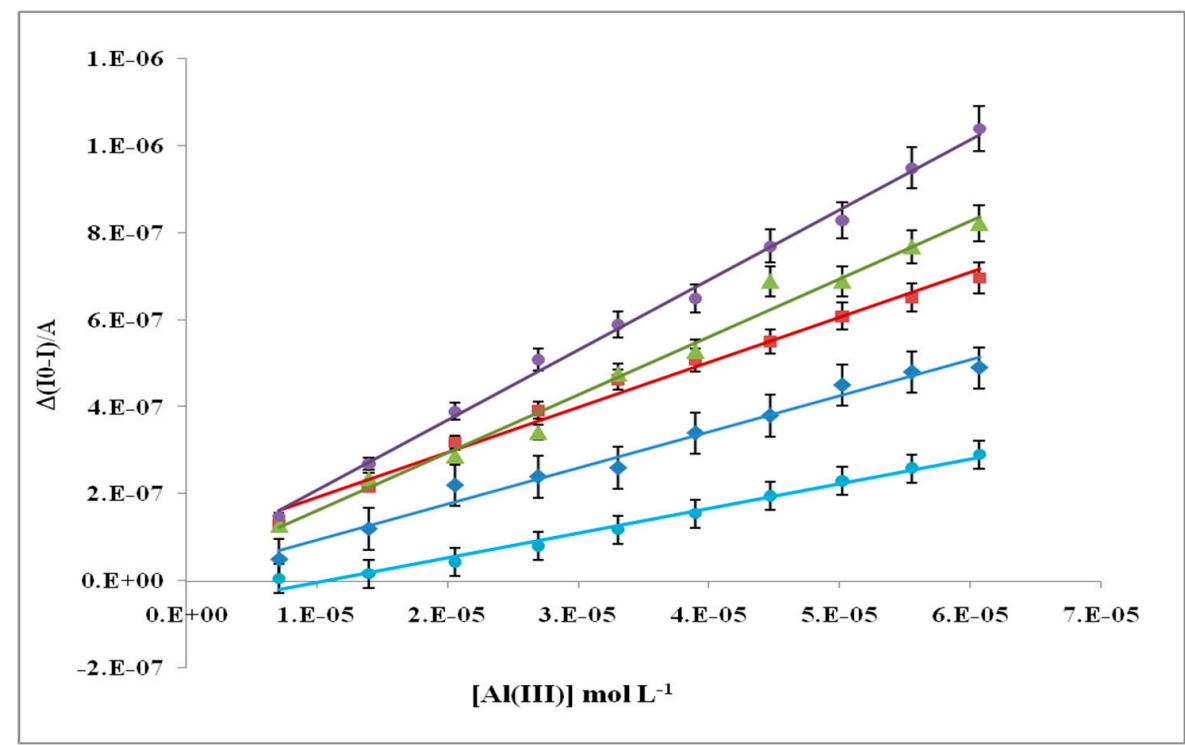

Figure 3. Calibration plots using: (•) SOD/AuNPs/SPC $\mathrm{TTF}_{\mathrm{Es}}$ ( $\square$ ) SOD/PdNPs/SPC $\mathrm{TTF}_{\mathrm{TS}}$; $(\Delta)$ $\mathrm{SOD} / \mathrm{RhNPs} / \mathrm{SPC}_{\mathrm{TTF}} \mathrm{Es}$; $(\diamond) \mathrm{SOD} / \mathrm{PtNPs} / \mathrm{SPC}_{\mathrm{TTF}}$ Es and (•) $\mathrm{SPC}_{\mathrm{TTF}}$ Es performed with NPs/SPC $\mathrm{TTF}_{\mathrm{Es}}$ prepared by method A, [EPI] $1.6 \times 10^{-4} \mathrm{M}$, Britton Robinson buffer $\mathrm{pH} 5.0$, Eap $=+0.2 \mathrm{~V}$ vs. Ag/ AgCl. 


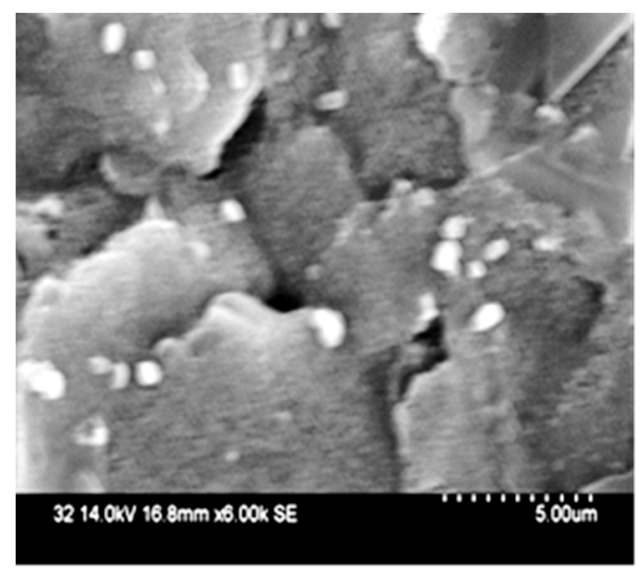

Figure 4. SEM image of AuNPs/SPC $\mathrm{TTF}_{\mathrm{E}}$ deposited at $0.18 \mathrm{~V}$ for $15 \mathrm{~s}$.

\subsection{XRF and SEM for NPS/SPC TTFES Study METHOD B}

XRF percentagesforevery metal deposited with method B are shown in Table 1. AuNPs, PtNPs, PdNPs and RhNPs were deposited on SPC $_{\mathrm{TTF}}$ Es according to method $\mathrm{B}$ and modified with immobilized SOD. SOD/SPCEs modified with metallic NPs showed the best linear adjustedAl(III) calibration curve at CV1 conditions for PtNPs and at CV2 conditions for PdNPs (Figures 5 and 6). Regressions with the best linear fit performed by methods $\mathrm{A}$ and $\mathrm{B}$ showed that the highest slope corresponds to

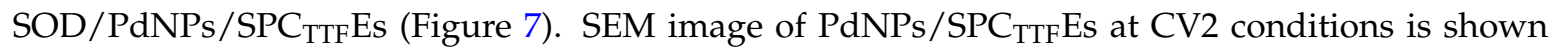
in Figure 8, where it is observed that PdNPs are deposited in a regular form on $\mathrm{SPC}_{\mathrm{TTF}}$ Es for the CV2 conditions.

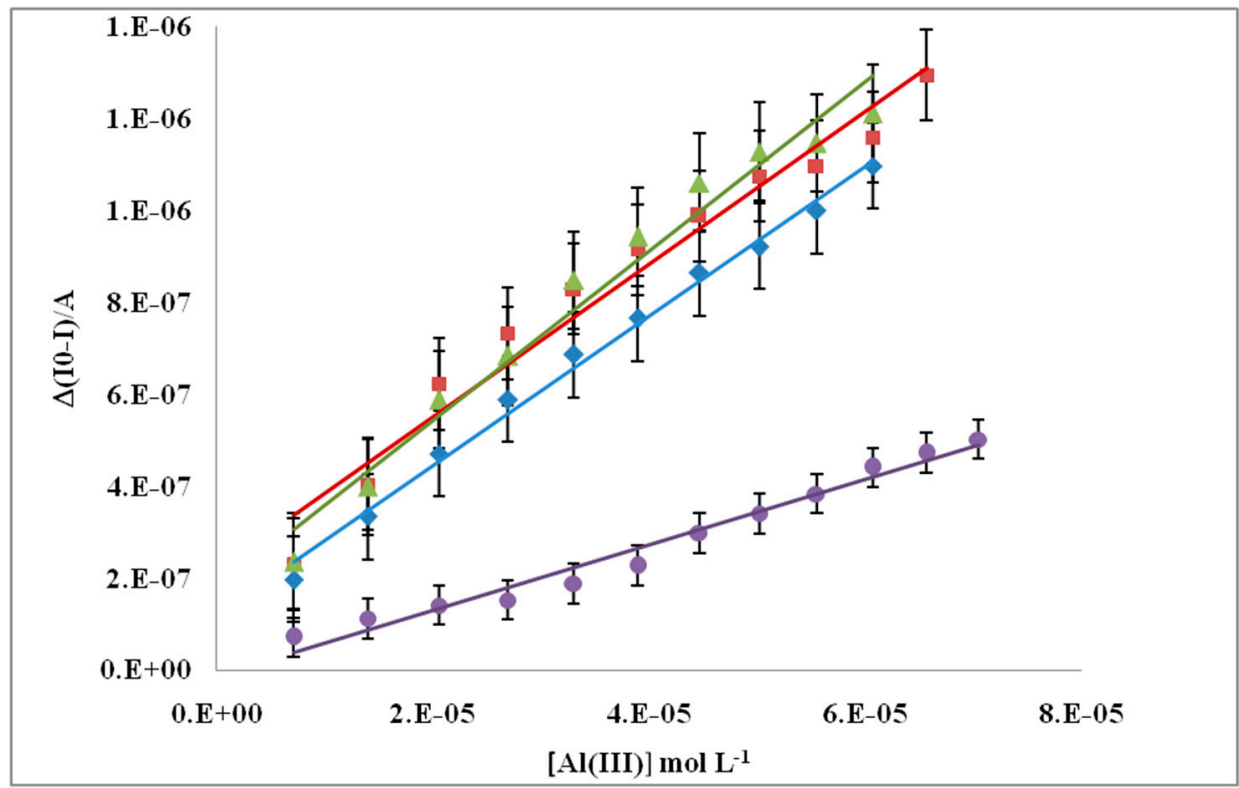

Figure 5. Calibration curves of $\mathrm{Al}(\mathrm{III})$ inhibition for $(\triangle) \mathrm{SOD} / \mathrm{RhNPs} / \mathrm{SPC}_{\mathrm{TTF}} \mathrm{Es}$;

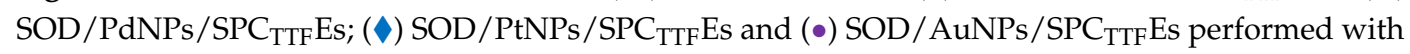
NPs $/ \mathrm{SPC}_{\mathrm{TTF}}$ Es prepared under CV1 condition, [EPI] $1.6 \times 10^{-4} \mathrm{M}$, Britton Robinson buffer pH 5.0, Eap $=+0.2$ V vs. Ag/ AgCl. 


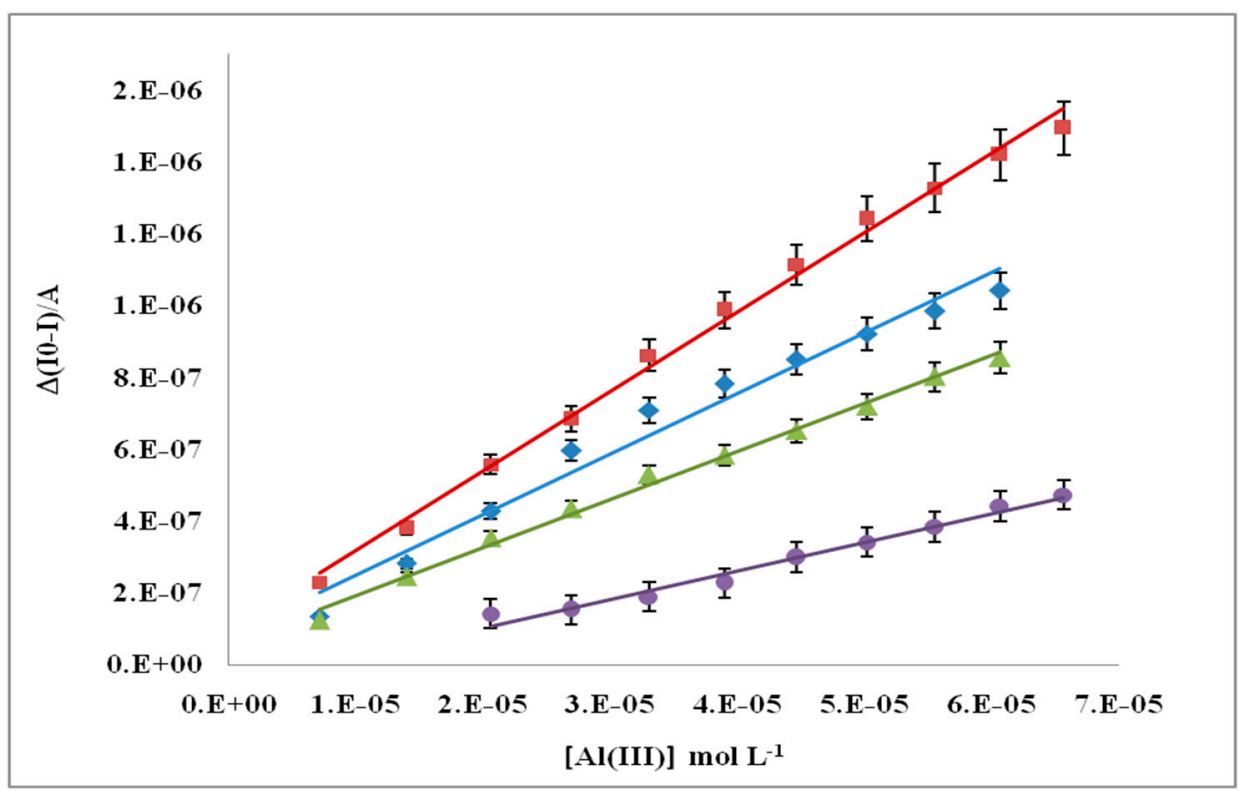

Figure 6. Calibration curves of $\mathrm{Al}(\mathrm{III})$ inhibition for (口) SOD/PdNPs/SPC $\mathrm{TTF}_{\mathrm{Es}}$; $(\diamond)$ SOD/PtNPs/SPC TTF Es; $(\triangle)$ SOD/RhNPs/SPC TTFEs and $(\bullet)$ SOD/AuNPs/SPC $_{\text {TTF }}$ Es performed with NPs $/ \mathrm{SPC}_{\mathrm{TTF}}$ Es prepared under CV2 conditions, [EPI] $1.6 \times 10^{-4} \mathrm{M}$, Britton Robinson buffer $\mathrm{pH}$ 5.0; Eap = 0.2 V vs. Ag/ AgCl.

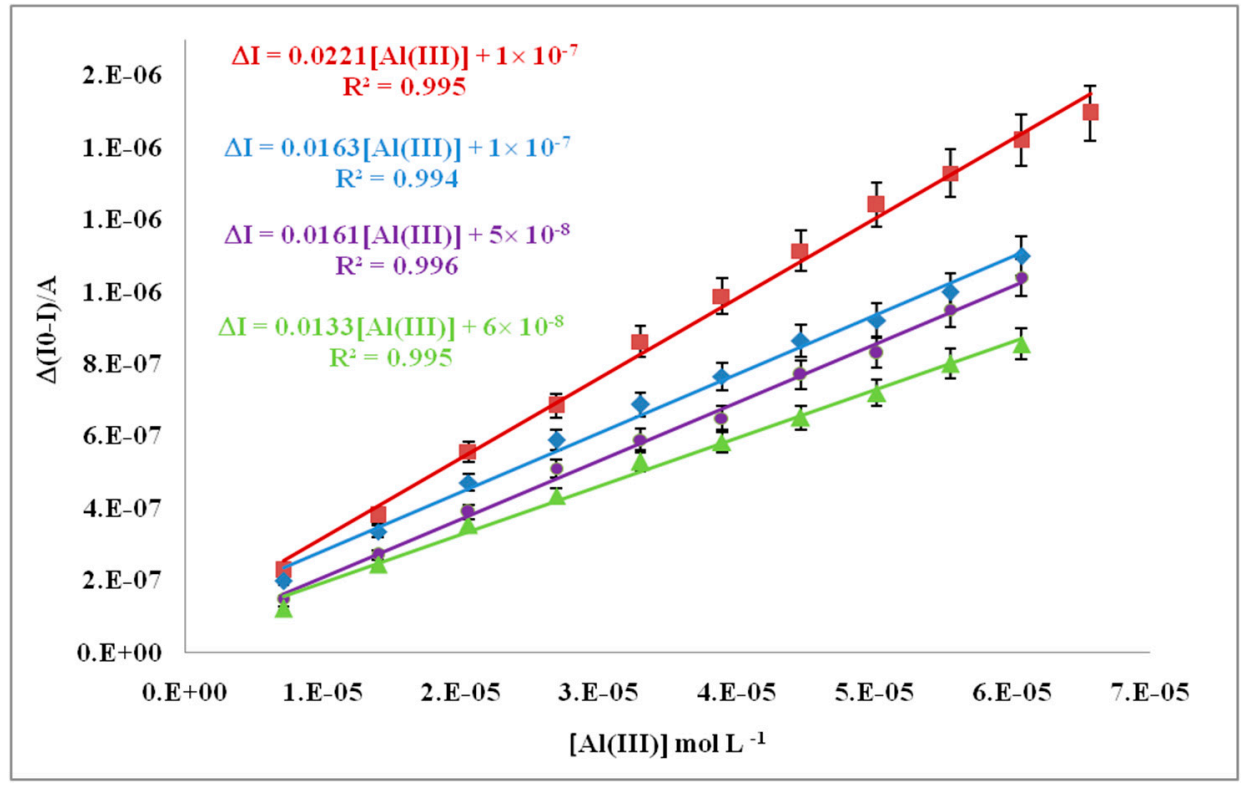

Figure 7. Calibration curves of $\mathrm{Al}(\mathrm{III})$ for $(\square)$ SOD/PdNPs/SPC $\mathrm{TTF}$ Es; $(\triangle)$ SOD/RhNPs/SPC $\mathrm{TTF}_{\mathrm{Es}}$ prepared method B; CV2 conditions; $(\checkmark) \mathrm{SOD} / \mathrm{PtNPs} / \mathrm{SPC}_{\mathrm{TTF}} \mathrm{Es}$, prepared by method $\mathrm{B}$ and CV1 conditions and $(\bullet) \mathrm{SOD} / \mathrm{AuNPs} / \mathrm{SPC}_{\mathrm{TTF}}$ Es, prepared by method A, [EPI] $=1.6 \times 10^{-4} \mathrm{M}$, Britton Robinson buffer $\mathrm{pH}$ 5.0, Eap $=+0.2 \mathrm{~V}$ vs. Ag/ AgCl. 


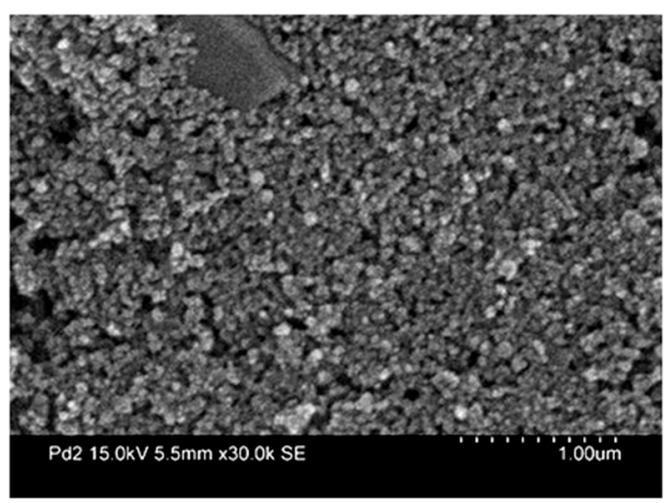

Figure 8. SEM image of PdNPs /SPC $\mathrm{TTF}_{\mathrm{F}} \mathrm{E}$ prepared by method $\mathrm{B}$ and $\mathrm{CV} 2$ conditions.

\subsection{AFM Analysis of $S P C_{T T F}$ Es Prepared by Methods $A$ and $B$}

AuNPs deposit on $\mathrm{SPC}_{\mathrm{TTF}} \mathrm{E}$ increases roughness of $\mathrm{SPC}_{\mathrm{TTF}} \mathrm{E}$ compared with control electrode,

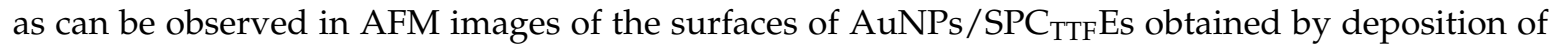
AuNPs at $0.18 \mathrm{~V}$ for $15 \mathrm{~s}$ (Figure 9). The highest slope presented for SOD/AuNPs/SPC $\mathrm{TTF}_{\mathrm{E}} \mathrm{E}$ using method A is afforded by lower AFM parameters of AuNPs at $0.18 \mathrm{~V}$ for $15 \mathrm{~s}$, than when the CV1or CV2 conditions are used. AFM images of PdNPs $/$ SPC $_{\mathrm{TTF}}$ Es obtained by deposition of PdNPs at CV1 and CV2 conditions are shown in Figure 10. Analysis of AFM parameters confirmed that metal deposited was nanometric size. Table 3 shows the most important parameters of NPs $/ \mathrm{SPC}_{\mathrm{TTF}}$ Es and $\mathrm{SPC}_{\mathrm{TTF}} \mathrm{Es}$ control electrode obtained through tapping mode and Roughness Kurtosis (RKu) and Skewness (RSk)

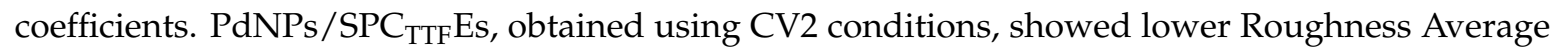
(RA), Roughness Mean Square (RMS) and height of the highest peak above mean line in the profile (Rmax) than other $\mathrm{SPC}_{\mathrm{TTF}}$ Es modified with metallic NPs, indicating that PdNPs/SPC $\mathrm{TTF}_{\mathrm{TF}}$ Es prepared by CV2 condition present a more homogeneous surface [62]. AFM image of PdNPs prepared by CV2 method showed lower values of RA andRMS when compared tosurface prepared by CV1 method.

Table 3. AFM parameters of modified $\mathrm{SPC}_{\mathrm{TTF}}$ Es with metallic NPs.

\begin{tabular}{|c|c|c|c|c|c|c|}
\hline $\mathrm{NPs} / \mathrm{SPC}_{\mathrm{TTF}} \mathrm{Es}$ & Method/Conditions & RA (nm) & RMS (nm) & $\operatorname{Rmax}(\mathrm{nm})$ & $\mathbf{R K u}$ & RSk \\
\hline $\mathrm{SPC}_{\mathrm{TTF}} \mathrm{E}$ & - & 16.8 & 21.5 & 131 & 3.53 & -0.183 \\
\hline \multirow{3}{*}{ AuNPs $/ \mathrm{SPC}_{\mathrm{TTF}} \mathrm{E}$} & $\mathrm{A} / 0.18 \mathrm{~V}$ & 31.3 & 39.2 & 218 & 3.34 & -0.537 \\
\hline & B/CV1 & 33.8 & 41.4 & 234 & 2.62 & 0.126 \\
\hline & $\mathrm{B} / \mathrm{CV} 2$ & 34.6 & 44.5 & 303 & 3.19 & -00292 \\
\hline \multirow{2}{*}{ PdNPs $/ S_{\text {TTF }}$ E } & $\mathrm{B} / \mathrm{CV} 1$ & 24.8 & 34.6 & 216 & 4.72 & 0.0604 \\
\hline & $\mathrm{B} / \mathrm{CV} 2$ & 14.7 & 18.2 & 106 & 2.69 & 0.0939 \\
\hline \multirow{2}{*}{ PtNPs $/$ SPC $_{\mathrm{TTF}} \mathrm{E}$} & $\mathrm{B} / \mathrm{CV} 1$ & 106 & 140 & 864 & 3.63 & 0.157 \\
\hline & $\mathrm{B} / \mathrm{CV} 2$ & 106 & 140 & 864 & 3.60 & 0.141 \\
\hline \multirow{2}{*}{ RhNPs/SPC ${ }_{T T F} E$} & $\mathrm{~B} / \mathrm{CV} 1$ & 22.0 & 28.1 & 173 & 3.30 & -0.0733 \\
\hline & $\mathrm{B} / \mathrm{CV} 2$ & 25.6 & 33.9 & 204 & 3.65 & -0.189 \\
\hline
\end{tabular}




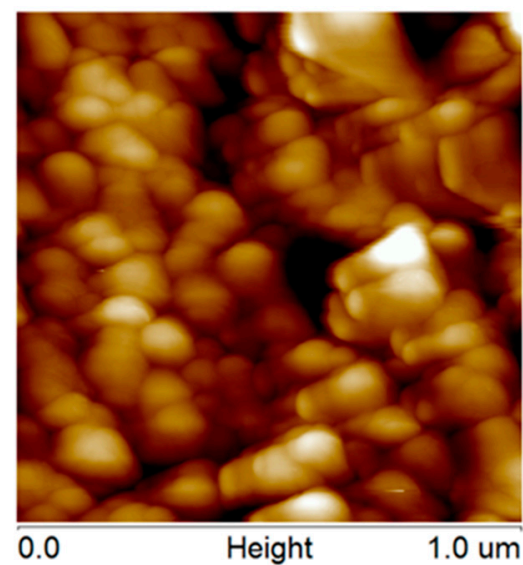

(a)

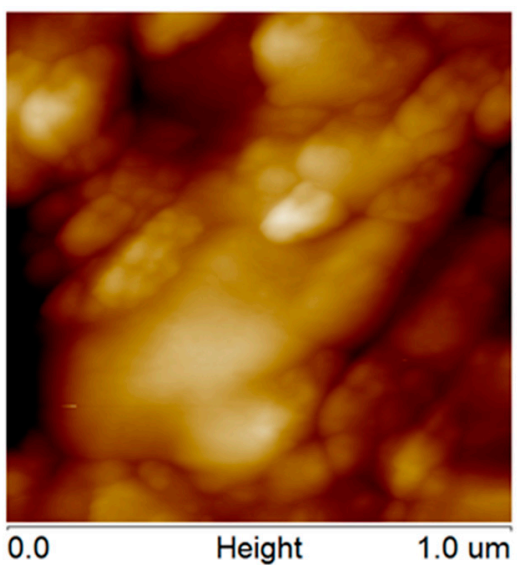

(b)

Figure 9. (a) AFM image for $\mathrm{SPC}_{\mathrm{TTF}} \mathrm{E}$ control electrode; and (b) AFM image for AuNPs/SPC $\mathrm{TTF}_{\mathrm{E}}$ prepared by plating at $0.18 \mathrm{~V}$ for $15 \mathrm{~s}$.

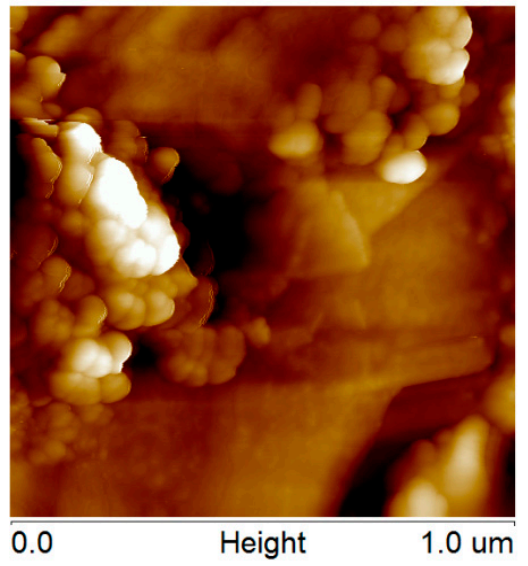

(a)

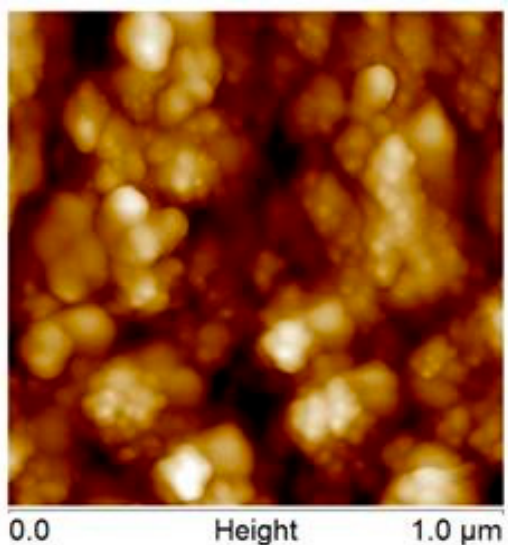

(b)

Figure 10. (a) AFM image of PdNPs/SPC $\mathrm{TTF}_{\mathrm{E}} \mathrm{E}$ prepared under method $\mathrm{B}$ andCV1conditions; and (b) AFM image of PdNPs/SPC $\mathrm{TTF}_{\mathrm{E}}$ prepared under method B and CV2 conditions.

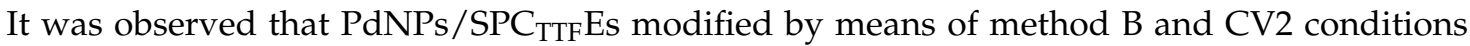

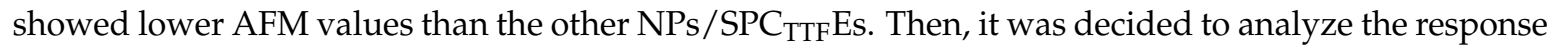
of EPI at SOD/NPs/SPC ${ }_{\mathrm{TTF}}$ Es in presence of aluminum.

\subsection{Inhibition Behavior of Al(III) on SOD Enzyme}

Michaelis Menten $\mathrm{Km}$ apparent constants were estimated by Lineweaver-Burk plot. It was obtained in presence and absence of $\mathrm{Al}(\mathrm{III})$ with $\mathrm{SPC}_{\mathrm{TTF}}$ Es modified with AuNPs, PtNPs, RhNPs and PdNPs. Modified electrodes were prepared under the best conditions for each NP deposition method used, namely $0.18 \mathrm{~V}$ for method A and CV2 conditions for method B. Figure 11 shows amperometric recording of SOD/PdNPs $/ \mathrm{SPC}_{\mathrm{TTF}} \mathrm{Es}$ (obtained by method $\mathrm{B}$ and $\mathrm{CV} 2$ conditions). 


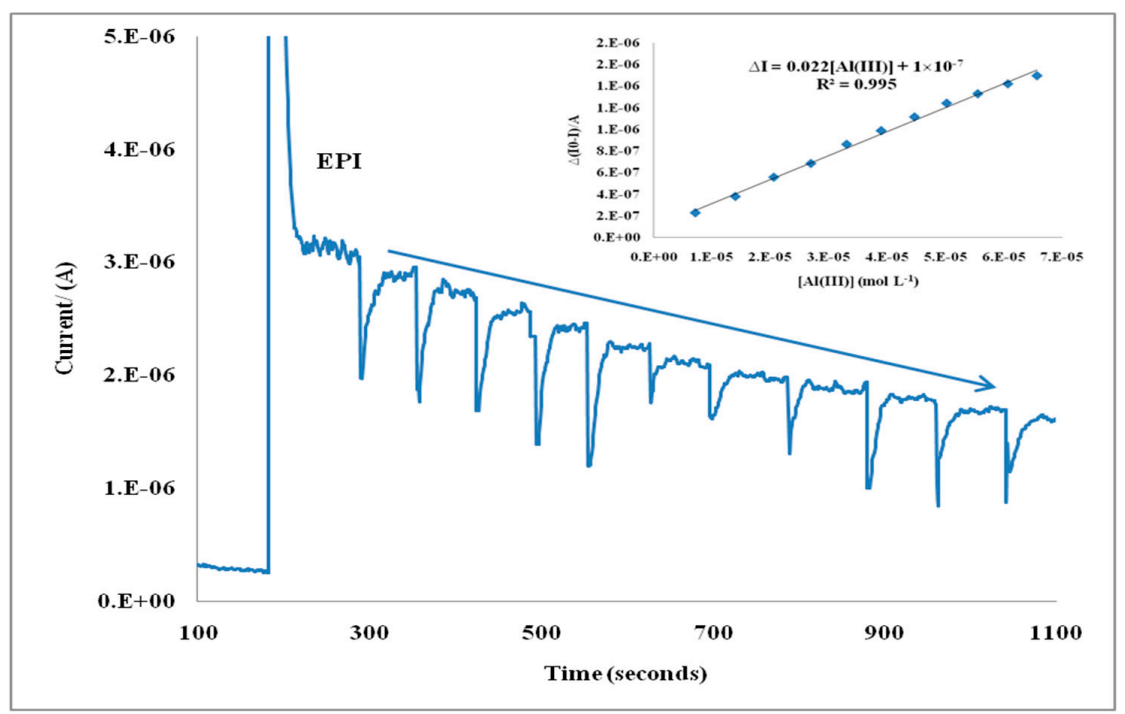

Figure 11. Amperometric recording performed with $\mathrm{SOD} / \mathrm{PdNPs} / \mathrm{SPC}_{\mathrm{TTF}} \mathrm{E}$, prepared under method $\mathrm{B}$ and $\mathrm{CV} 2$ conditions, $[\mathrm{EPI}]=1.6 \times 10^{-4} \mathrm{M}$ and consecutive additions of $100 \mu \mathrm{L}$ of $\mathrm{Al}$ (III) $3.7 \times 10^{-4} \mathrm{M}$ into the cell, Britton Robinson buffer $\mathrm{pH} 5.0$, Eap $=+0.20 \mathrm{~V}$ vs. Ag/ AgCl. Inset: Calibration curve corresponding to this amperogram.

Km apparent values of modified electrodes are shown in Table 4.

Table 4. Km apparent values for $\mathrm{SPC}_{\mathrm{TTF}}$ Es modified with AuNPs, PtNPs, RhNPs, and PdNPs.

\begin{tabular}{|c|c|c|c|c|}
\hline Km Apparent (M) & SOD/AuNPs/SPC & SOD/PtNPs/SPC & SOD/PdNPs/SPC & SOD/RhNPs/SPC \\
\hline \multicolumn{5}{|c|}{ Method A $0.18 \mathrm{~V}$} \\
\hline Without Al & $(7.8 \pm 0.3) \times 10^{-4}$ & $(1.2 \pm 0.3) \times 10^{-4}$ & $(1.5 \pm 0.4) \times 10^{-3}$ & $(3.3 \pm 0.2) \times 10^{-3}$ \\
\hline $\mathrm{Al}(\mathrm{III}) 7.25 \times 10^{-6} \mathrm{M}$ & $(1.3 \pm 0.1) \times 10^{-3}$ & $(1.4 \pm 0.3) \times 10^{-2}$ & $(1.0 \pm 0.1) \times 10^{-2}$ & $(1.4 \pm 0.1) \times 10^{-2}$ \\
\hline $\mathrm{Al}(\mathrm{III}) 2.18 \times 10^{-5} \mathrm{M}$ & $(3.7 \pm 0.3) \times 10^{-3}$ & $(1.8 \pm 0.6) \times 10^{-2}$ & $(1.3 \pm 0.1) \times 10^{-2}$ & - \\
\hline \multicolumn{5}{|c|}{ Method B and CV2 conditions } \\
\hline Without Al & $(1.5 \pm 0.2) \times 10^{-3}$ & $(5.8 \pm 0.3) \times 10^{-4}$ & $(1.5 \pm 0.3) \times 10^{-3}$ & $(1.2 \pm 0.1) \times 10^{-4}$ \\
\hline $\mathrm{Al}(\mathrm{III}) 7.25 \times 10^{-6} \mathrm{M}$ & $(2.7 \pm 0.4) \times 10^{-3}$ & $(1.3 \pm 0.4) \times 10^{-3}$ & $(5.0 \pm 0.4) \times 10^{-3}$ & $(6.4 \pm 0.5) \times 10^{-3}$ \\
\hline $\mathrm{Al}(\mathrm{III}) 2.18 \times 10^{-5} \mathrm{M}$ & $(3.05 \pm 0.5) \times 10^{-3}$ & $(3.0 \pm 0.8) \times 10^{-3}$ & $(1.2 \pm 0.3) \times 10^{-2}$ & $(5.4 \pm 0.2) \times 10^{-3}$ \\
\hline
\end{tabular}

\subsection{Validation of SOD/PdNPS/TTF/SPCE Based Biosensor}

$\mathrm{SOD} / \mathrm{PdNPs} / \mathrm{SPC}_{\mathrm{TTF}}$ Es were selected to perform validation of the developed biosensor trough estimation of their performance parameters.

\subsubsection{Limit of Detection}

The limit of detection under the optimum working conditions $(2.0 \pm 0.2 \mu \mathrm{M})$ was calculated from the standard deviation (Sy/x) of five Al(III) inhibition calibration curves according to the criteria 3 Sy/x [63], and its RSD was 7.9\%. Analogous to LOD, quantification limit (LOQ) was estimated under optimal conditions from the standard deviation of five Al(III)inhibition calibration curves using the criteria $10 \mathrm{Sy} / \mathrm{x}$, and its value was $6.7 \pm 0.5 \mu \mathrm{M}$, with a RSD of $7.9 \%$.

\subsubsection{Precision}

This parameter is usually calculated in terms of reproducibility and repeatability. Repeatability was assessed using the same electrode surface. In this way, successive calibrations for $\mathrm{Al}(\mathrm{III})$ were tested with SOD/PdNPs $/ \mathrm{SPC}_{\mathrm{TTF}}$ Es prepared under $\mathrm{CV} 2$ conditions. The electrodes were conditioned in a Britton Robinson buffer solution, $\mathrm{pH} 5.0$, stirring for $5 \mathrm{~min}$ between experiments. The RSD 
obtained for the slopes of the first two graphs was 5.1\%, but, in the third measurement, a decrease in the biosensor sensitivity and a RSD increase, reaching $15 \%$, were observed. Because the electrodes are disposables, the reproducibility is a better estimate of performance. Likewise, the reproducibility of the amperometric signal was checked using the slopes of five regression lines carried out with different electrode surfaces, RSD slope value estimated was 7.0\%.

\subsubsection{Accuracy}

The accuracy of the developed method was tested by a recovery study in which a known amount of $\mathrm{Al}(\mathrm{III})$ standard reference material (SRM), SRM High Purity Standards solution (Lot Number $\left.1121015,(1000 \pm 3) \mathrm{mg} \cdot \mathrm{L}^{-1}\right)$ was spiked to a buffer solution.

The aluminum average concentration quantified by the developed procedure, $1038 \pm 50 \mathrm{mg} \cdot \mathrm{L}^{-1}$ ( $n=5 ; \alpha=0.05)$, matches the certified value of the sample considering the associated uncertainty. The mean recovery percentage obtained was $(103.8 \pm 4.8) \%$. Recovery values are shown in Table 5. SRM was spiked to tap water replicates, SRM aluminum average concentration found was $1005 \pm 34 \mathrm{mg} \cdot \mathrm{L}^{-1}(\mathrm{n}=3 ; \alpha=0.05)$. Mean recovery percentage obtained was $(100.5 \pm 3.4) \%$. Recovery values are shown in Table 6.

Table 5. Recovery of Al(III) SRM (1000 mg/L $\pm 3 \mathrm{mg} / \mathrm{L})$ spiked to buffer solution.

\begin{tabular}{ccccc}
\hline Added SRM & Found SRM & Found SRM & SRM & Recovery \\
\hline$(\mathrm{M})$ & $(\mathrm{M})$ & $(\mathrm{mg} / \mathrm{L})$ & $(\mathrm{mg} / \mathrm{L})$ & - \\
$1.30 \times 10^{-5}$ & $1.235 \times 10^{-5}$ & 9.50 & 950 & 95.0 \\
- & $1.366 \times 10^{-5}$ & 10.51 & 1051 & 105.1 \\
- & $1.370 \times 10^{-5}$ & 10.51 & 1051 & 105.3 \\
- & $1.374 \times 10^{-5}$ & 10.58 & 1058 & 105.8 \\
- & $1.402 \times 10^{-5}$ & 10.79 & 1079 & 107.9 \\
- & - & Mean & 1038 & 103.8 \\
- & - & SD & 50.3 & 5.0 \\
- & - & RSD & 4.8 & 4.8 \\
\hline
\end{tabular}

Table 6. Recovery of SRM (1000 mg/L $\pm 3 \mathrm{mg} / \mathrm{L})$ spiked to tap water.

\begin{tabular}{ccccc}
\hline Added SRM (mg/L) & Found SRM (mg/L) & SRM (mg/L) & SRM (mg/L) & Recovery (\%) \\
\hline \multirow{2}{*}{0.170} & 0.180 & 10.44 & 1044 & 104.0 \\
& 0.171 & 9.90 & 990 & 99.0 \\
- & 0.169 & 9.82 & 982 & 98.2 \\
- & - & Mean & 1005 & 100.5 \\
- & - & SD & 34 & 3.4 \\
& - & RSD & 3.4 & 3.4 \\
\hline
\end{tabular}

\subsection{Study of Interferences on $S O D / P d N P S / S P C_{T T F}$ E Biosensors}

Interference study was performed comparing the percentage of inhibition showed by the developed SOD based biosensor in the presence of aluminum and other foreign ions. Three concentration levels of possible interfering ions, namely $1 \times 10^{-3} \mathrm{M}, 1 \times 10^{-4} \mathrm{M}$, and $1 \times 10^{-6} \mathrm{M}$, were tested. Regarding $\mathrm{Al}(\mathrm{III})$, LOD value obtained for SOD/PdNPs/SPC TTF $_{\mathrm{E}}$ is meaningful at $1 \times 10^{-4} \mathrm{M}$. As can be seen in Figure 12, the highest interference effect was found for $\mathrm{Sn}(\mathrm{II}), \mathrm{Cd}(\mathrm{II})$ and $\mathrm{Mo}(\mathrm{VI})$ for concentrations tested; however, these cations should usually not be present in water. 


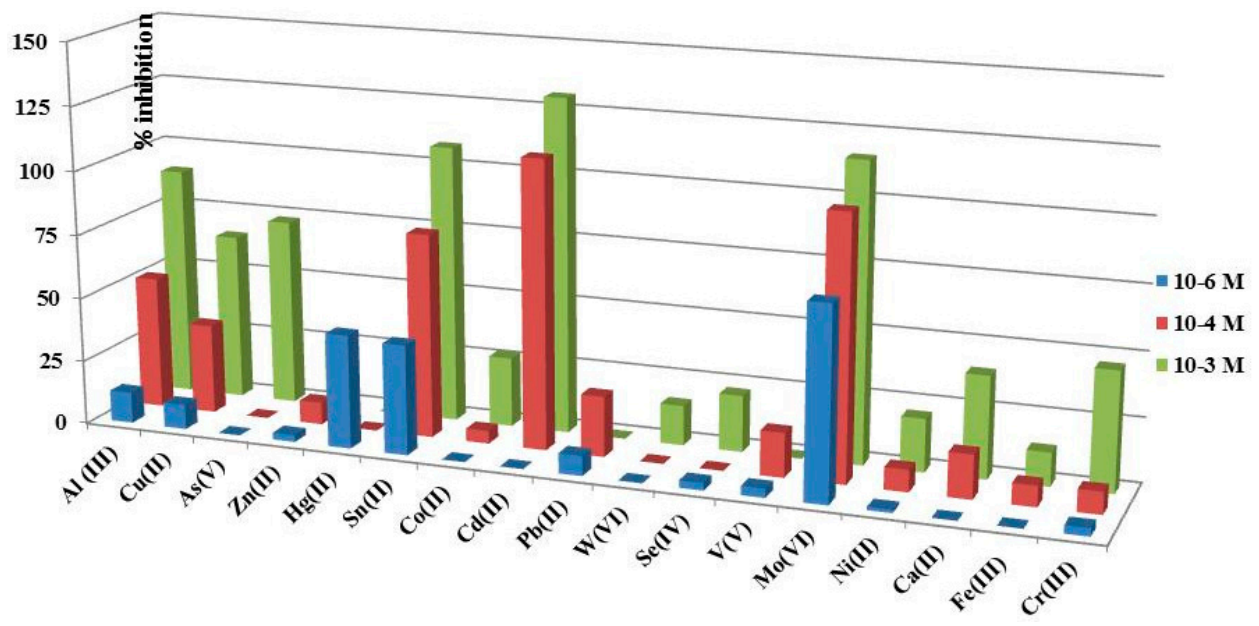

Figure 12. Inhibition percentage of current at $\mathrm{SOD} / \mathrm{PdNPs} / \mathrm{SPC}_{\mathrm{TTF}} \mathrm{E}$, (method $\mathrm{B}$ and $\mathrm{CV} 2$ conditions) in presence of: $\mathrm{Al}(\mathrm{III}), \mathrm{Cu}(\mathrm{II}), \mathrm{As}(\mathrm{V}), \mathrm{Zn}(\mathrm{II}), \mathrm{Hg}(\mathrm{II}), \mathrm{Sn}(\mathrm{II}), \mathrm{Co}(\mathrm{II}), \mathrm{Cd}(\mathrm{II}), \mathrm{Pb}(\mathrm{II}), \mathrm{W}(\mathrm{VI}), \mathrm{Se}(\mathrm{IV}), \mathrm{V}(\mathrm{V})$, $\mathrm{Mo}(\mathrm{VI}), \mathrm{Ni}(\mathrm{II}), \mathrm{Ca}(\mathrm{II}), \mathrm{Fe}(\mathrm{III})$ and $\mathrm{Cr}(\mathrm{III})$ at three concentration levels; [EPI] $=1.6 \times 10^{-4} \mathrm{M}$; Britton Robinson buffer pH 5.0, Eap $=+0.2 \mathrm{~V}$ vs. Ag/ AgCl.

\section{Discussion}

SOD biosensor was developed looking for effect of metallic NPs on sensibility of slopes of Al(III) calibration curves. One initial hypothesis was that NPs generation methodology influence sensitivity of biosensor. For these reasons, two different methodologies to deposit NPs were tested, direct deposit at $0.18 \mathrm{~V}$ produced the highest slope for AuNPs, CV2 deposit methodology produced the highest slope for PdNPs, followed for RhNPs andCV1 deposit methodology produced the highest slope for PtNPs. Criteria used for slope selection were linearity and sensibility. Regarding all optimum slopes values obtained with $\mathrm{SOD} / \mathrm{NPs} / \mathrm{SPC}_{\mathrm{TTF}}$ Es biosensors under the two methodologies, the highest slope value was obtained for SOD/PdNPs/SPC $\mathrm{TTF}_{\mathrm{TF}}$ Es based biosensor. NPs' physical characteristics are also modified by deposit methodologies.Although SEM were performed on every NPs $/ \mathrm{SPC}_{\mathrm{TTF}}$ Es prepared by means of the above-mentioned methodologies and NPs were visualized, AFM is a more appropriate

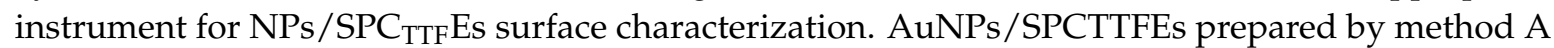
showed lower AFM parameters, namely RA, RMS and Rmax, than CV deposition methodologies.

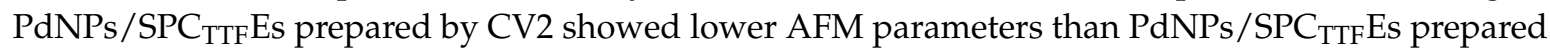
by CV1. Although PtNPs/SPC ${ }_{\mathrm{TTF}}$ Es prepared by CV2/CV1 showed similar AFM values and slopes, best linearity was obtained for $\mathrm{CV} 2$ condition. RhNPs $/ \mathrm{SPC}_{\mathrm{TTF}}$ Es prepared under $\mathrm{CV} 2$ condition showed much better linearity than CV1. All RKu values are near 3, providing evidence that the obtained values are closer to a normal distribution, and the surface is named Mesokurtic, for kurtosis minor 3, surface is flat and called Platykurtic. When kurtosis is greater than 3, surface owns more peaks than valleys. RSk measures the profile of symmetry about mean line. If the height distribution is asymmetrical and the surface has more peaks than valleys, skewness is positive, while in the opposite case, skewness is negative.

SOD/NPs/SPC $\mathrm{TTF}_{\mathrm{Es}}$ based biosensor was based on $\mathrm{Al}(\mathrm{III})$ inhibition of SOD, and $\mathrm{Km}$ inhibition were estimated for SOD/NPs/SPC $\mathrm{TTF}_{\mathrm{T}}$ Es under method $\mathrm{A}$ andCV2 condition. It was established that $\mathrm{Al}(\mathrm{III})$ exerts its inhibitory action at low concentration. Inhibitory effect for SOD/NPs/SPC $\mathrm{TTF}$ Es was confirmed by means of $\mathrm{Km}$ app values with $\mathrm{Al}(\mathrm{III})$ increasing concentrations. This fact is in accordance with theoretical considerations regarding enzymatic behavior in presence of inhibitors. However, the last measurement for $\mathrm{SOD} / \mathrm{RhNPs} / \mathrm{SPC}_{\mathrm{TTF}} \mathrm{Es}$, displayed an unusual behavior.

$\mathrm{SOD} / \mathrm{PdNPs} / \mathrm{SPC}_{\mathrm{TTF}}$ Es were selected to perform validation of the developed biosensor. The selection was based on the Al(III) inhibition calibration curves of SOD enzyme, that clearly showed higher sensibility by modifying SPC $_{\text {TTF }}$ Es with PdNPs prepared under method B and CV2 


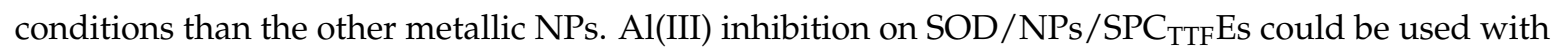
analytical purposes, but at first it is necessary to perform developed biosensor validation. This goal was achievedby performance parameters estimation. Precision was established through reproducibility of calibration curves slope, as $\mathrm{SPC}_{\mathrm{TTF}}$ Es are disposable, and this reproducibility is a good precision estimate. LOD and LOQ values allowed quantification of low $\mathrm{Al}(\mathrm{III})$ concentrations. Recovery

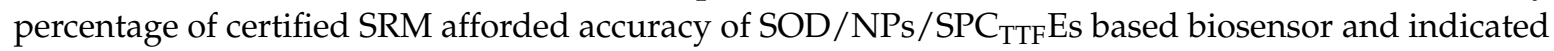

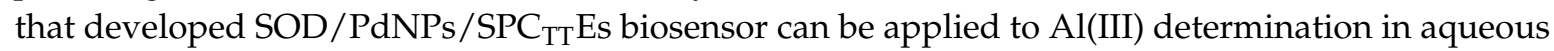
solutions.Validation results suggest that the fabrication procedure of the SOD/PdNPs $/ \mathrm{SPC}_{\mathrm{TTF}}$ Es based biosensor is reliable and allows reproducible amperometric responses to be obtained with different electrodes constructed using the method described in this work.

A weakness of biosensor SOD/PdNPs/SPC $\mathrm{TTF}_{\mathrm{T}}$ Es is its response to interfering ions, but these toxic ions should not be naturally present in water. $\mathrm{Ca}$ (II) and Fe(III) usually found in water do not interfere. $\mathrm{Al}(\mathrm{III})$ showed inhibition on SOD enzyme at all tested concentrations.

\section{Conclusions}

A novel amperometric biosensor based on SOD/PdNPs $/ \mathrm{C}_{\mathrm{TTF}} / \mathrm{SPCEs}$ was developed, validated and applied to $\mathrm{Al}$ (III) determination in aqueous matrixes. The biosensor was based on inhibitory effect of $\mathrm{Al}(\mathrm{III})$ on SOD enzyme and presents fast response, very good reproducibility, stability, and low LOD. Michaelis Menten constants were calculated from Lineweaver-Burk plots and showed increasing values with $\mathrm{Al}(\mathrm{III})$ concentration in accordance with theory of enzymatic inhibition.

SOD enzyme immobilization was easily and rapidly achieved by crosslinking using glutaraldehyde and allowed obtaining a good reproducibility value of biosensor.

Modification of $\mathrm{SPC}_{\mathrm{TTF}}$ Es with different types of NPs improves biosensor performance. A study of electrolytic generation conditions of NPs of $\mathrm{Au}, \mathrm{Pt}, \mathrm{Rh}$ and Pd onto SPC $\mathrm{TTF}$ E surface was carried out and results showed that $\mathrm{SPC}_{\mathrm{TTF}}$ Es modified with PdNPs by means of cyclic voltammetry under method B and CV2 conditions (delay time $120 \mathrm{~s}$, step potential, $0.025 \mathrm{~V}$, scan rate $0.1 \mathrm{~V} / \mathrm{s}$ ) gave a higher sensibility on amperometric inhibition of $\mathrm{Al}(\mathrm{III})$ calibration curves.

SEM images showed presence of the metallic NPs deposited on $\mathrm{SPC}_{\mathrm{TTF}}$ Es. XRF study was conducted to evaluate percentages of every metal deposited on $\mathrm{SPC}_{\mathrm{TTF}}$ Es. In addition, AFM study showed roughness, characteristic of $\mathrm{SPC}_{\mathrm{TTF}}$ Es and NPs/SPC $\mathrm{TTF}_{\mathrm{E}}$ s surfaces and provided useful information about morphology and surface homogeneity. It was also found that PdNPs/SPC deposited by method B and CV2 conditions had lower RA, RSM and Rmax than the others metallic NPs.

Biosensor validation was performed under optimized conditions: $\mathrm{pH}$ 5.0, applied potential of $0.2 \mathrm{~V}$ and a concentration of EPI of $1.6 \times 10^{-4} \mathrm{M}$. The recovery value obtained using certified material, supported the feasibility of SOD/PdNPs/SPC ${ }_{\mathrm{TTF}}$ Es based biosensor for Al(III) determination.

Developed biosensor presents LOD similar to other developed Al(III) biosensors, but it has the advantage of using a lower applied potential of only $+0.2 \mathrm{~V}$. The possibility of using this biosensor at low potentials results in a muchhigher selectivity compared with the others Al(III) biosensors.

Acknowledgments: Authors would like to acknowledge funding from the Vice-presidency for Research at the University of Costa Rica (Project 804-B5-117), Ministerio de Ciencia e Innovación (MICINN Spain) and Fondo Europeo de Desarrollo Regional (FEDER) (Projects :TEC-TEC20013-40561-P and MUSSEL RTC-2015-4077-2).

Author Contributions: Miriam Barquero-Quirós and María Julia Arcos-Martínez conceived and designed the experiments; Miriam Barquero-Quirós performed the experiments; Miriam Barquero-Quirós and María Julia Arcos-Martínez analyzed the data; Miriam Barquero-Quirós wrote the paper; and María Julia Arcos-Martínez contributed $\mathrm{SPC}_{\mathrm{TTF}}$ Es manufacturing.

Conflicts of Interest: The authors declare no conflict of interest.

\section{References}

1. Exley, C. The coordination chemistry of aluminum in neurodegenerative disease. Coord. Chem. Rev. 2012, 256, 2142-2146. [CrossRef] 
2. Shin, R.W. Aluminum modifies the properties of Alzheimer's disease PHF tau proteins in vivo and in vitro. J. Neurosci. 1994, 14, 7221-7233. [PubMed]

3. Zatta, P.; Drago, D.; Bolognin, S.; Sensi, S.L. Alzheimer's disease, metal ions and metal homeostatic therapy. Trends Pharmacol. Sci. 2009, 30, 346-353. [CrossRef] [PubMed]

4. Wu, Z.; Du, Y.; Xue, H.; Wu, Y.; Zhou, B. Aluminum induces neurodegeneration and its toxicity arises from increased iron accumulation and reactive oxygen species (ROS) production. Neurobiol. Aging 2012, 33, 199.e1-199.e12. [CrossRef] [PubMed]

5. Tian, Y.; Mao, L.; Okajima, T.; Ohsaka, T. Superoxide Dismutase-Based Third-Generation Biosensor for Superoxide Anion. Anal. Chem. 2002, 74, 2428-2434. [CrossRef] [PubMed]

6. Rahman, M.A.; Kothalam, A.; Choe, E.S.; Won, M.S.; Shim, Y.B. Stability and Sensitivity Enhanced Electrochemical In Vivo Superoxide Microbiosensor Based on Covalently Co-immobilized Lipid and Cytochrome c. Anal. Chem. 2012, 84, 6654-6660. [CrossRef] [PubMed]

7. Wilson, G.S.; Johnson, M.A. In-Vivo Electrochemistry: What Can We Learn about Living Systems? Chem. Rev. 2008, 108, 2462-2481. [CrossRef] [PubMed]

8. Luo, X.; Jia, S.; Ma, Q.; Zhong, M.; Gao, P.; Yu, Z.; Zhang, Y. Suppressive Effects of Subchronic Aluminum Overload on the Splenic Immune Function May Be Related to Oxidative Stress in Mice. Biol. Trace Elem. Res. 2014, 157, 249-255. [CrossRef] [PubMed]

9. Joshi, D.K.; Tripathi, S.; Kulshrestha, S.; Mahdi, A.A. Docosahexaenoic acid ameliorates aluminum induced biochemical and morphological alteration in rat cerebellum. Ann. Neurosci. 2014, 21, 5-9. [CrossRef] [PubMed]

10. Razo-Estrada, A.C.; García-Medina, S.; Madrigal-Bujaidar, E.; Gómez-Oliván, L.M.; Galar-Martínez, M. Aluminum-Induced Oxidative Stress and Apoptosis in Liver of the Common Carp, Cyprinus Carpio. Water Air Soil Poll. 2013, 224, 1510-1518. [CrossRef]

11. Bhasin, P.; Singla, N.; Dhawan, D.K. Protective role of zinc during aluminum-induced hepatotoxicity. Environ. Toxicol. 2014, 29, 320-327. [CrossRef] [PubMed]

12. Viezeliene, D.; Beekhof, P.; Gremmer, E.; Rodovicius, H.; Sadauskiene, I.; Jansen, E.; Ivanov, L. Selective induction of IL-6 by aluminum-induced oxidative stress can be prevented by selenium. J. Trace Elem. Med. Biol. 2013, 27, 226-229. [CrossRef] [PubMed]

13. Sivakumar, S.; Khatiwada, C.P.; Sivasubramanian, J.; Raja, B. Protective Effects of Deferiprone and Desferrioxamine in Brain Tissue of Aluminum Intoxicated Mice: An FTIR Study. Biomed. Prev. Nutr. 2014, 4, 53-61. [CrossRef]

14. Yu, L.; Jiang, R.; Su, Q.; Yu, H.; Yang, J. Hippocampal neuronal metal ion imbalance related oxidative stress in a rat model of chronic aluminum exposure and neuroprotection of meloxicam. Behav. Brain Funct. 2014, 10, 6-10. [CrossRef] [PubMed]

15. Jelenković, A.; Jovanović, M.D.; Stevanović, I.; Petronijević, N.; Bokonjić, D.; Živković, J.; Igić, R. Influence of the Green Tea Leaf Extract on Neurotoxicity of Aluminium Chloride in Rats: Green Tea and Aluminium Neurotoxicity. Phytother. Res. 2014, 28, 82-87. [CrossRef] [PubMed]

16. Li, X.; Han, Y.; Guan, Y.; Zhang, L.; Bai, C.; Li, Y. Aluminum Induces Osteoblast Apoptosis through the Oxidative Stress-Mediated JNK Signaling Pathway. Biol. Trace Elem. Res. 2012, 150, 502-508. [CrossRef] [PubMed]

17. Celik, H.; Celik, N.; Kocyigit, A.; Dikilitas, M. The relationship between plasma aluminum content, lymphocyte DNA damage, and oxidative status in persons using aluminum containers and utensils daily. Clin. Biochem. 2012, 45, 1629-1633. [CrossRef] [PubMed]

18. Alonso-Lomillo, M.A.; Domínguez-Renedo, O.; Arcos-Martínez, M.J. Screen-printed biosensors in microbiology; a review. Talanta 2010, 82, 1629-1636. [CrossRef] [PubMed]

19. Andreescu, S.; Njagi, J.; Ispas, C. The New Frontiers of Organic and Composite Nanotechnology; Elsevier: Oxford, UK, 2008; pp. 355-394.

20. Siangproh, W.; Dungchai, W.; Rattanarat, P.; Chailapakul, O. Nanoparticle-based electrochemical detection in conventional and miniaturized systems and their bioanalytical applications: A review. Anal. Chim. Acta 2011, 690, 10-25. [CrossRef] [PubMed]

21. Xia, T.; Kovochich, M.; Brant, J.; Hotze, M.; Sempf, J.; Oberley, T.; Sioutas, C.; Yeh, J.I.; Wiesner, M.R.; $\mathrm{Nel}$, A.E. Comparison of the Abilities of Ambient and Manufactured Nanoparticles to Induce Cellular Toxicity According to an Oxidative Stress Paradigm. Nano Lett. 2006, 6, 1794-1807. [CrossRef] [PubMed] 
22. Domínguez-Renedo, O.; Alonso-Lomillo, M.A.; Arcos-Martínez, M.J. Recent developments in the field of screen-printed electrodes and their related applications. Talanta 2007, 73, 202-219. [CrossRef] [PubMed]

23. Domínguez-Renedo, O.; Alonso-Lomillo, M.A.; Recio-Cebrián, P.; Arcos-Martínez, M.J. Screen-printed acetylcholinesterase-based biosensors for inhibitive determination of permethrin. Sci. Total Environ. 2012, 426, 346-350. [CrossRef] [PubMed]

24. Dai, X.; Nekrassova, O.; Hyde, M.E.; Compton, R.G. Anodic Stripping Voltammetry of Arsenic(III) Using Gold Nanoparticle-Modified Electrodes. Anal. Chem. 2004, 76, 5924-5929. [CrossRef] [PubMed]

25. Alonso-Lomillo, M.A.; Yardimci, C.; Domínguez-Renedo, O.; Arcos-Martínez, M.J. CYP450 2 B4 covalently attached to carbon and gold screen printed electrodes by diazonium salt and thiols monolayers. Anal. Chim. Acta 2009, 633, 51-56. [CrossRef] [PubMed]

26. Domínguez Renedo, O.; Arcos-Martínez, M.J. Anodic stripping voltammetry of antimony using gold nanoparticle-modified carbon screen-printed electrodes. Anal. Chim. Acta 2007, 589, 255-260. [CrossRef] [PubMed]

27. Dua, D.; Ding, J.; Cai, J.; Zhang, J.; Liu, L. In situ electrodeposited nanoparticles for facilitating electron transfer across self-assembled monolayers in biosensor design. Talanta 2008, 74, 1337-1343. [CrossRef] [PubMed]

28. Del Torno-de Román, L.; Alonso-Lomillo, M.A.; Domínguez-Renedo, O.; Merino-Sánchez, C.; Merino-Amayuelas, M.P.; Arcos-Martínez, M.J. Fabrication and characterization of disposable sensors and biosensors for detection of formaldehyde. Talanta 2011, 86, 324-328. [CrossRef] [PubMed]

29. Rand, E.; Periyakaruppan, A.; Tanaka, Z.; Zhang, D.A.; Marsh, M.P.; Andrews, R.J.; Lee, K.H.; Chen, B.; Meyyappan, M.; Koehne, J.E. A carbon nanofiber based biosensor for simultaneous detection of dopamine and serotonin in the presence of ascorbic acid. Biosens. Bioelectron. 2008, 24, 632-637.

30. Araque, E.; Arenas, C.B.; Gamella, M.; Reviejo, J.; Villalonga, R.; Pingarrón, J.M. Graphene-polyamidoamine dendrimer-Pt nanoparticles hybrid nanomaterial for the preparation of mediatorless enzyme biosensor. J. Electroanal. Chem. 2014, 717-718, 96-102. [CrossRef]

31. Wang, S.Q.; Lu, L.P.; Lin, X.Q. A selective voltammetric method for uric acid detection at a glassy carbon electrode modified with electrodeposited film containing DNA and $\mathrm{Pt}-\mathrm{Fe}_{2} \mathrm{O}_{3}$ nanocomposites. Electroanalysis 2004, 16, 1734-1738. [CrossRef]

32. Sanllorente-Méndez, S.; Domínguez-Renedo, O.; Arcos-Martínez, M.J. Determination of Arsenic(III) Using Platinum Nanoparticle-Modified Screen-Printed Carbon-Based Electrodes. Electroanalysis 2009, 21, 635-639. [CrossRef]

33. Thiagarajan, S.; Yang, R.F.; Chen, S.M. Palladium nanoparticles modified electrode for the selective detection of catecholamine neurotransmitters in presence of ascorbic acid. Bioelectrochemistry 2009, 75, 163-169. [CrossRef] [PubMed]

34. Atta, N.F.; El-Kady, M.F. Novel poly (3-methylthiophene)/Pd, Pt nanoparticle sensor: Synthesis, characterization and its application to the simultaneous analysis of dopamine and ascorbic acid in biological fluids. Sens. Actuat. B 2010, 145, 299-310. [CrossRef]

35. Vitulli, G.; Evangelisti, C.; Pertici, P.; Caporusso, A.M.; Panziera, N.; Salvadori, P.; Faga, M.G.; Manfredotti, C.; Martra, G.; Coluccia, S.; et al. Supported rhodium nanoparticles in catalysis: The role of stabilizers on catalytic activity and structural features. J. Organomet. Chem. 2003, 681, 37-50. [CrossRef]

36. Zapf, R.; Thiele, R.; Wichert, M.; O'Connell, M.; Ziogas, A.; Kolb, G. Application of rhodium nanoparticles for steam reforming of propane in microchannels. Catal. Commun. 2013, 41, 140-145. [CrossRef]

37. Lokesh, K.S.; Shivaraj, Y.; Dayananda, B.P.; Chandra, S. Synthesis of phthalocyanine stabilized rhodium nanoparticles and their application in biosensing of cytochrome c. Bioelectrochemistry 2009, 75, 104-109. [CrossRef] [PubMed]

38. Chandra, S.; Lokesh, K.S.; Nicolai, A.; Lang, H. Dendrimer-rhodium nanoparticle modified glassy carbon electrode for amperometric detection of hydrogen peroxide. Anal. Chim. Acta 2009, 632, 63-68. [CrossRef] [PubMed]

39. Poorahong, S.; Santhosh, P.; Valdés, G.; Tseng, T.F.; Wong, J.I.; Kanatharan, P.; Thavarungkul, P.; Wang, J. Development of amperometric $\alpha$-ketoglutarate biosensor based on ruthenium-rhodium modified carbon fiber enzyme microelectrode. Biosens. Bioelectron. 2011, 26, 3670-3673. [CrossRef] [PubMed] 
40. Campanella, L.; Favero, G.; Persi, L.; Tomassetti, M. New biosensor for superoxide radical used to evidence molecules of biomedical and pharmaceutical interest having radical scavenging properties. J. Pharm. Biomed. Anal. 2000, 23, 69-76. [CrossRef]

41. Campanella, L.; Bonanni, A.; Finotti, E.; Tomassetti, M. Biosensors for determination of total and natural antioxidant capacity of red and white wines: Comparison with other spectrophotometric and fluorimetric methods. Biosens. Bioelectron. 2004, 19, 641-651. [CrossRef]

42. Campanella, L.; Favero, G.; Persi, L.; Tomassetti, M. Evaluation of radicals scavenging properties of several plants, fresh or from a herbalist's, using a superoxide dismutase biosensor. J. Pharm. Biomed. Anal. 2001, 24, 1055-1064. [CrossRef]

43. Campanella, L.; Bonanni, A.; Tomassetti, M. Determination of the antioxidant capacity of samples of different types of tea, or of beverages based on tea or other herbal products, using a superoxide dismutase biosensor. J. Pharm. Biomed. Anal. 2003, 32, 725-736. [CrossRef]

44. Campanella, L.; Bonanni, A.; Favero, G.; Tomassetti, M. Determination of antioxidant properties of aromatic herbs, olives and fresh fruit using an enzymatic sensor. Anal. Bioanal. Chem. 2003, 375, 1011-1016. [PubMed]

45. Campanella, L.; Martini, E.; Tomassetti, M. Antioxidant capacity of the algae using a biosensor method. Talanta 2005, 66, 902-911. [CrossRef] [PubMed]

46. Campanella, L.; Bonanni, A.; Bellantoni, D.; Tomassetti, M. Biosensors for determination of total antioxidant capacity of phytotherapeutic integrators: Comparison with other spectrophotometric, fluorimetric and voltammetric. J. Pharm. Biomed. Anal. 2004, 35, 303-320. [CrossRef]

47. Campanella, L.; Bonanni, A.; Bellantoni, D.; Favero, G.; Tomassetti, M. Comparison of fluorimetric, voltammetric and biosensor methods for the determination of total antioxidant capacity of drug products containing acetylsalicylic acid. J. Pharm. Biomed. Anal. 2004, 36, 91-99. [CrossRef] [PubMed]

48. Tomassetti, M.; Serone, M.; Angeloni, R.; Campanella, L.; Mazzone, E. Amperometric Enzyme Sensor to Check the Total Antioxidant Capacity of Several Mixed Berries. Comparison with Two Other Spectrophotometric and Fluorimetric Methods. Sensors 2015, 15, 3435-3452. [CrossRef] [PubMed]

49. Santharaman, P.; Das, M.; Singh, S.K.; Sethy, N.K.; Bhargava, K.; Claussen, J.C.; Karunakaran, C. Label-free electrochemical immunosensor for the rapid and sensitive detection of the oxidative stress marker superoxide dismutase 1 at the point-of-care. Sens. Actuators B 2016, 236, 546-553. [CrossRef]

50. Tian, Y.; Mao, L.; Okajima, T.; Ohsaka, T. A carbon fiber microelectrode-based third-generation biosensor for superoxide. Biosens. Bioelectron. 2005, 21, 557-564. [CrossRef] [PubMed]

51. Zhu, X.; Liu, T.; Zhao, H.; Shi, L.; Li, X.; Lan, M. Ultrasensitive detection of superoxide anion released from living cells using a porous Pt-Pd decorated enzymatic sensor. Biosens. Bioelectron 2016, 79, 449-456. [CrossRef] [PubMed]

52. Salem, F.; Tavakoli, H.; Sadeghi, M.; Riazi, A. Developing a high performance superoxide dismutase based electrochemical biosensor for radiation dosimetry of thallium 201. Radiat. Phys. Chem. 2014, 102, 128-134. [CrossRef]

53. Wang, Z.; Liu, D.; Gu, H.; Zhu, A.; Tian, Y.; Shi, G. NTA-modified carbon electrode as a general relaying substrate to facilitate electron transfer of SOD: Application to in vivo monitoring of $\mathrm{O}_{2}^{-}$in a rat brain. Biosens. Bioelectron. 2013, 43, 101-107. [CrossRef] [PubMed]

54. Campanella, L.; Favero, G.; Tomassetti, M. A modified amperometric electrode for the determination of free radicals. Sens. Actuators B 1997, 44, 559-565. [CrossRef]

55. Tang, J.; Zhu, X.; Niu, X.; Liu, T.; Zhao, H.; Lan, M. Anamperometric superoxide anion radical biosensor based on SOD/PtPd-PDARGO modified electrode. Talanta 2015, 137, 18-24. [CrossRef] [PubMed]

56. Braik, M.; Barsan, M.M.; Dridi, C.; Ali, M.B.; Brett, C.M.A. Highly sensitive amperometric enzyme biosensor for detection of superoxide based on conducting polymer/CNT modified electrodes and superoxide dismutase. Sens. Actuators B 2016, 236, 574-582. [CrossRef]

57. Ghica, M.E.; Brett, C.M.A. Simple and efficient epinephrine sensor based on carbon nanotube modified carbon film electrodes. Anal. Lett. 2013, 46, 1379-1393. [CrossRef]

58. Ruipérez, F.; Mujika, J.I.; Ugalde, J.M.; Exley, C.; Lopez, X. Pro-oxidant activity of aluminum: Promoting the Fenton reaction by reducing Fe(III) to Fe(II). J. Inorg. Biochem. 2012, 117, 118-123.

59. Thiagarajan, S.; Yang, R.F.; Chen, S.M. Palladium Nanoparticles Modified Electrode for the Selective Detection of Catecholamine Neurotransmitters in Presence of Ascorbic Acid. Bioelectrochemistry 2009, 75, 163-169. [CrossRef] [PubMed] 
60. Nunes, G.S.; Jeanty, G.; Marty, J.L. Enzyme immobilization procedures on screen-printed electrodes used for the detection of anticholinesterase pesticides: Comparative study. Anal. Chim. Acta 2004, 523, 107-115. [CrossRef]

61. Alonso-Lomillo, M.A.; Domínguez-Renedo, O.; Arcos-Martínez, M.J. Enzyme Modified Screen Printed Electrodes in Biosensors: Properties, Materials and Applications; Nova Science Publishers: New York, NY, USA, 2009.

62. Raposo, M.; Ferreira, Q.; Ribeiro, P.A. A Guide for Atomic Force Microscopy Analysis of Soft Condensed Matter. Mod. Res. Educ. Top. Microsc. 2007, 1, 758-769.

63. Miller, J.C.; Miller, J.N. Estadística y Quimiometría para Química Analítica; Prentice Hall: Madrid, Spain, 2002.

(C) 2016 by the authors; licensee MDPI, Basel, Switzerland. This article is an open access article distributed under the terms and conditions of the Creative Commons Attribution (CC-BY) license (http://creativecommons.org/licenses/by/4.0/). 